University of Rhode Island

DigitalCommons@URI

Open Access Master's Theses

1990

\title{
ROLE OF INTRACELLULAR THIOL STATIUS AND CALCIUM HOMEOSTASIS IN MYOCARDIAL CELL INJURY
}

Cyrus M. Dhanbhoora

University of Rhode Island

Follow this and additional works at: https://digitalcommons.uri.edu/theses

\section{Recommended Citation}

Dhanbhoora, Cyrus M., "ROLE OF INTRACELLULAR THIOL STATIUS AND CALCIUM HOMEOSTASIS IN MYOCARDIAL CELL INJURY" (1990). Open Access Master's Theses. Paper 242.

https://digitalcommons.uri.edu/theses/242

This Thesis is brought to you for free and open access by DigitalCommons@URI. It has been accepted for inclusion in Open Access Master's Theses by an authorized administrator of DigitalCommons@URI. For more information, please contact digitalcommons-group@uri.edu. 
ROLE OF INTRACELLULAR THIOL STATUS AND CALCIUM HOMEOSTASIS

IN MYOCARDIAL CELL INJURY

BY

CYRUS M. DHANBHOORA

A THESIS SUBMITTED IN PARTIAL FULFILLMENT OF THE

REQUIREMENTS FOR THE DEGREE OF

MASTER OF SCIENCE

IN PHARMACOLOGY AND TOXICOLOGY

UNIVERSITY OF RHODE ISLAND

1990 
MASTER OF SCIENCE THESIS

OF

CYRUS M. DHANBHOORA

APPROVED:

Thesis Committee

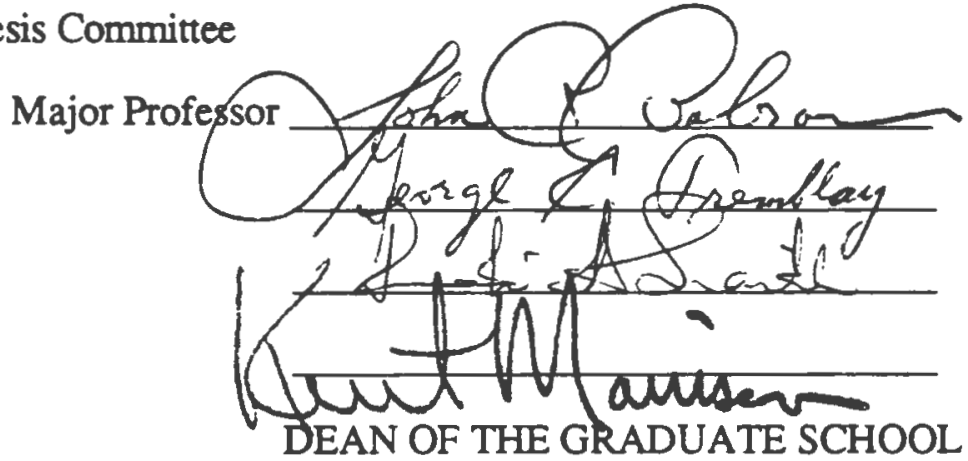

UNIVERSITY OF RHODE ISLAND 


\begin{abstract}
The primary biochemical mechanisms involved in chemically-induced cell injury remain to be elucidated. Elevation of intracellular $\mathrm{Ca}^{2+}$ is a common feature to cell death due to a wide array of toxic chemicals, and on this basis hypotheses have been put forth suggesting that the chemically-induced elevation of cytosolic $\mathrm{Ca}^{2+}$ is responsible for the onset of cell death. The mechanism by which elevated $\mathrm{Ca}^{2+}$ causes cell damage may involve activation of $\mathrm{Ca}^{2+}$-dependent proteases, phospholipases and endonucleases (2). Previous evidence suggests that a link between intracellular thiol status and $\mathrm{Ca}^{2+}$ homeostasis exists $(1,2)$. Based on these observations, it has been speculated that thiol depletion may lead to an elevation of intracellular $\mathrm{Ca}^{2+}$ to cytotoxic levels $(1,2,4)$.

Glutathione, the major cellular thiol, is primarily a defense mechanism against cytotoxic reaction to oxidative stress or alkylating agents. Glutathione also plays an important role in maintaining protein thiols in a reduced state, which is required for their normal enzymatic activity $(6,7)$. Such enzymes include the sarcolemmal and sarcoplasmic reticular $\mathrm{Ca}^{2+}$-ATPase's, which are involved in the maintenance of low levels of cytosolic $\mathrm{Ca}^{2+}$. Therefore depletion of intracellular glutathione may limit the capacity of these enzymes with modified thiol groups to maintain low levels of cytosolic $\mathrm{Ca}^{2+}(10,11)$. The loss of GSH as an antioxidant may promote oxidative stress and the resultant peroxidative damage to plasma membrane may be an alternate cause of cell death by a $\mathrm{Ca}^{2+}$-independent mechanism. The relative importance of elevated cytosolic free $\mathrm{Ca}^{2+}$ or oxidative stress in cell death, in the face of a chemical challenge that alters intracellular thiol status is the subject of this thesis.
\end{abstract}

Our approach towards this problem was to create a chemical model of oxidative stress in cardiomyocytes using ethacrynic acid. Ethacrynic acid depletes thiols by alkylation with a subsequent increase in cytosolic free $\mathrm{Ca}^{2+}$, thereby permitting us to examine lethal cell injury due to thiol depletion, including the proposed link to $\mathrm{Ca}^{2+}$ homeostasis. Exposure 
of primary rat myocardial cells to ethacrynic acid $(150 \mu \mathrm{M})$ resulted in a rapid (within 7 $\mathrm{min}$ ) loss of glutathione and protein thiols that preceded an increase in cytosolic free $\mathrm{Ca}^{2+}$ levels (within $45 \mathrm{~min}$ ), as detected by the activation of phosphorylase $a$. The leakage of cytosolic lactate dehydrogenase due to loss of membrane integrity was used as a criterion of loss of cell viability. All of these biochemical events preceded the loss of cell viability, thus permitting us to examine whether thiol depletion or changes in cytosolic free $\mathrm{Ca}^{2+}$ had the primary effect on the loss of cell viability.

Pretreatment of cells with specific intracellular $\mathrm{Ca}^{2+}$ chelators, Quin-2acetoxymethylester and EGTA-acetoxymethylester, were used in an attempt to sequester $\mathrm{Ca}^{2+}$, in order to prevent an ethacrynic acid-induced elevation of intracellular $\mathrm{Ca}^{2+}$. Both intracellular chelators reduced lactate dehydrogenase leakage, protected against lipid peroxidation, but failed to reduce the marked elevation of intracellular $\mathrm{Ca}^{2+}$. The latter observation required examination of the mechanism of protection afforded by the putative chelators. The antioxidant N,N'-Diphenyl-p-phenylenediamine was employed to investigate the importance of lipid peroxidation in ethacrynic acid-induced cell death. N,N'-Diphenyl-p- phenylenediamine reduced lipid peroxidation and lethal cell injury to control levels but had no effect on intracellular glutathione and $\mathrm{Ca}^{2+}$ levels. Thus, it would appear that the antioxidant activity of the putative chelators might account for their protection. The possibility that cytotoxicity was due to an ethacrynic acid-induced alteration of cellular energy status was also examined. Ethacrynic acid had no significant effect on cellular ATP levels or mitochondrial membrane potential.

In our model of myocardial cell injury the temporal relationship observed between the loss of intracellular thiol status and $\mathrm{Ca}^{2+}$ homeostasis supports the hypothesis that thiol status is linked to $\mathrm{Ca}^{2+}$. However elevated $\mathrm{Ca}^{2+}$ levels alone, had no effect on cell viability over the time course we observed, further supporting that peroxidative damage is a requisite event for cell death in our model of myocardial cell injury. 


\section{ACKNOWLEDGEMENT}

The author would like to thank Dr. John R. Babson for his utmost patience, moral support, and guidance throughout the course of this study.

I would like to dedicate this thesis in loving memory of my uncle Dr. Rusi K. Dastoor, who unknowingly helped mold my career and outlook to life. I would also like to dedicate this work to my parents and my girlfriend Pia for their undying love and support. Without their love, support, and understanding, this work would not have been completed. Finally, I would like to thank special friends Michael Christe, Mark Blazka, Gunturi Srinivas, and Nancy Gavitt for all their help. 


\section{PREFACE}

This thesis was prepared according to the manuscript format. The manuscript will be submitted to Biochemical Pharmacology. 
TABLE OF CONTENTS

PAGE

ABSTRACT ii

ACKNOWLEDGEMENTS iv

PREFACE $\quad$ v

TABLE OF CONTENTS vi

LIST OF FIGURES/TABLES vii

$\begin{array}{ll}\text { ABSTRACT } & 2\end{array}$

$\begin{array}{ll}\text { INTRODUCTION } & 4\end{array}$

MATERIALS AND METHODS

RESULTS 11

DISCUSSION

$\begin{array}{ll}\text { REFERENCES } & 47\end{array}$

BIBLIOGRAPHY $\quad 52$ 


\section{LIST OF FIGURESTTABLES}

PAGE

MANUSCRIPT

FIGURE 1: Concentration-dependent effect of ethacrynic acid on cardiomyocyte cell viability

FIGURE 2: Time-dependent effect of ethacrynic acid on cardiomyocyte cell viability... 18

FIGURE 3: Effect of ethacrynic acid on cardiomyocyte GSH levels...................... 20

FIGURE 4: Time-dependent effect of ethacrynic acid on cardiomyocyte protein thiol levels.

FIGURE 5: Time-dependent effect of ethacrynic acid on cardiomyocyte phosphorylase $a$ activity.

FIGURE 6: Effect of $\mathrm{Ca}^{2+}$ chelators on ethacrynic acid-induced cell injury 26

FIGURE 7: Effect of $\mathrm{Ca}^{2+}$ chelators on ethacrynic acid-induced phosphorylase $a$ activity.

FIGURE 8: Effect of $\mathrm{Ca}^{2+}$ chelators (Quin-2 AM and EGTA AM) and antioxidant DPPD on ethacrynic acid-induced phospholipase $c$ activity

FIGURE 9: Effect of antioxidant DPPD on ethacrynic acid-induced cell injury 32

FIGURE 10: Effect of antioxidant DPPD on ethacrynic acid-induced phosphorylase $a$ activity.

FIGURE 11: Effect of $\mathrm{Ca}^{2+}$ chelators (Quin-2 AM and EGTA AM) and antioxidant DPPD on ethacrynic acid-induced lipid peroxidation

FIGURE 12: Time-dependent effect of ethactynic acid on cardiomyocyte mitochondrial membrane potential

FIGURE 13: Effect of $\mathrm{Ca}^{2+}$ chelators (Quin-2 AM and EGTA AM) and antioxidant DPPD on ethacrynic acid-induced inactivation of G3PD activity

TABLE 1: Effect of antioxidant DPPD on ethacrynic acid-induced cardiomyocyte GSH depletion .................................................................. 41

TABLE 2: Time-dependent effect of ethacrynic acid on cardiomyocyte ATP levels .... 42 
ROLE OF INTRACELLULAR THIOL STATUS AND CALCIUM HOMEOSTASIS IN MYOCARDIAL CELL INJURY 


\section{ABSTRACT}

Ethacrynic acid, was used to deplete intracellular thiols to create a model of oxidative stress in order to examine the ensuing events leading to myocardial cell injury. Exposure of primary rat myocardial cells to ethacrynic acid resulted in a rapid loss of glutathione and protein thiols that preceded an increase in cytosolic free $\mathrm{Ca}^{2+}$ levels, as detected by the activation of phosphorylase $a$. The magnitude of lethal cell injury, using leakage of lactate dehydrogenase as a criterion, was dependent on the ethacrynic acid concentration used. The loss of cellular thiols and the elevation of intracellular $\mathrm{Ca}^{2+}$ preceded the onset of cell death. Pretreatment of cells with specific intracellular $\mathrm{Ca}^{2+}$ "chelators, Quin-2- acetoxymethylester and EGTA- acetoxymethylester, were used in an attempt to sequester $\mathrm{Ca}^{2+}$ and thereby prevent an ethacrynic acid-induced elevation of intracellular $\mathrm{Ca}^{2+}$, in this model system of chemically-induced cell killing. Both intracellular chelators reduced leakage of lactate dehydrogenase, protected against lipid peroxidation, but failed to reduce the marked elevation of intracellular $\mathrm{Ca}^{2+}$. The latter observation required examination of the mechanism of protection afforded by the putative chelators. The antioxidant $\mathrm{N}, \mathrm{N}$-Diphenyl-p-phenylenediamine was employed to investigate the importance of lipid peroxidation in ethacrynic acid-induced cell death. $\mathrm{N}, \mathrm{N}$-Diphenyl-p-phenylenediamine reduced lipid peroxidation and lethal cell injury to control levels but had no effect on intracellular glutathione and $\mathrm{Ca}^{2+}$ levels. Thus, one could postulate that the antioxidant activity of the putative chelators might account for their protective properties. An alternative possibility that cytotoxicity was due to an ethacrynic acid-induced alteration of cellular energy status was also examined. Ethacrynic acid had no significant effect on cellular ATP levels or release of the triphenylmethylphosphonium cation, a measure of mitochondrial membrane potential. These results support previous observations that a loss of intracellular thiols is followed by a rise in $\mathrm{Ca}^{2+}$, and the 
perturbation of these homeostases may result in the loss of cell viability. However the elevated $\mathrm{Ca}^{2+}$ alone was not responsible for cell death over the time course we observed, and oxidative damage was seen to be a primary requisite for myocardial cell injury. 


\section{INTRODUCTION}

An elevation of intracellular $\mathrm{Ca}^{2+}$ is a response that is frequently observed following exposure to a wide variety of toxic chemicals (1). This observation led to the hypothesis that chemically-induced elevation of cytosolic $\mathrm{Ca}^{2+}$ is a causative event in the cytotoxic mechanism of many chemicals (2). Attempts to understand how chemicals perturb intracellular $\mathrm{Ca}^{2+}$ homeostasis have provided evidence that suggests the elevation of cytosolic $\mathrm{Ca}^{2+}$ is a direct result of thiol depletion $(1,2)$. However, it may be the oxidative stress that results from thiol depletion, and not the accompanying rise in $\mathrm{Ca}^{2+}$, that is responsible for cell death $(2,4,6)$. Based on all of these observations, two different mechanisms have been proposed to explain chemically-induced cell injury: 1. A $\mathrm{Ca}^{2+}$-dependent mechanism of cytotoxicity involving a perturbation of $\mathrm{Ca}^{2+}$ homeostasis that triggers $\mathrm{Ca}^{2+}$-activated processes that are ultimately responsible for cell death. 2. A $\mathrm{Ca}^{2+}$-independent mechanism in which cell death is caused by peroxidative damage that results from the loss of glutathione (GSH) as an antioxidant.

GSH, a thiol tripeptide, is a major component of intracellular thiol status and is also a primary cellular defense mechanism against toxic chemical insult $(1,2,4)$. GSH is distributed intracellularly in two main pools. The mitochondrial pool contains $15 \%$ and the cytosolic pool contains $85 \%$ of the total intracellular GSH. GSH protects the cell against toxic challenges via two distinct mechanisms. First, it detoxifies alkylating agents by its ability to form conjugates either directly or enzymatically via GSH-S-transferases $(8,9)$. Second, GSH protects cells against oxidative stress by its ability to reduce chemical oxidants through the GSH redox cycle (6). Some studies have suggested that the depletion of mitochondrial GSH is a key factor in the onset of cell death (7).

GSH is also involved in the normal functioning of cells, including the maintenance of protein thiol status (6). The reducing equivalents provided by GSH maintain the activity of 
many cellular enzymes, which require that certain protein thiols be in the reduced state for enzymatic activity (10). Included in this group of enzymes are the sarcolemmal and sarcoplasmic reticular $\mathrm{Ca}^{2+}$-ATPase's believed to be involved in the sequestration and extrusion of cytosolic free $\mathrm{Ca}^{2+}(10,11)$. Since protein thiols may also be alkylated by toxic chemicals, GSH provides a nucleophilic barrier that protects protein thiols from alkylation. Accordingly, any event resulting in GSH depletion may lead to an alteration of key enzyme thiols, and subsequently limit the capacity of these enzymes to regulate intracellular $\mathrm{Ca}^{2+}$ levels (7).

Under normal physiological conditions the cytosolic free $\mathrm{Ca}^{2+}$ concentrations are quite low, ranging between 50 and $200 \mathrm{nM}$ (14). It has been proposed that many toxic chemicals may elevate cytosolic free $\mathrm{Ca}^{2+}$ by a combination of two processes. First, they are believed to promote the release of intracellular $\mathrm{Ca}^{2+}$ stores or the influx of extracellular $\mathrm{Ca}^{2+}$ by mechanisms that have yet to be determined. Second, by inhibiting $\mathrm{Ca}^{2+}$-ATPase activities responsible for removing $\mathrm{Ca}^{2+}$ from the cytosol, the chemical challenges are believed to elevate cytosolic free $\mathrm{Ca}^{2+}(12,15,24)$. Whether extracellular or intracellular $\mathrm{Ca}^{2+}$ is the primary source of elevated cytosolic free $\mathrm{Ca}^{2+}$ observed in lethal cell injury $(18,19)$, is beyond the scope of this study. Regardless of the source or mechanism, any chemical insult that promotes a sustained elevation of cytosolic $\mathrm{Ca}^{2+}$, including those that deplete intracellular thiols, may ultimately cause lethal cell injury due to a variety of $\mathrm{Ca}^{2+}$ activated processes (2). Elevated cytosolic $\mathrm{Ca}^{2+}$ could be expected to activate several $\mathrm{Ca}^{2+}$-dependent enzymes, including $\mathrm{Ca}^{2+}$-activated proteases, $\mathrm{Ca}^{2+}$-activated phospholipases, and $\mathrm{Ca}^{2+}$-activated endonucleases $(1,2,20)$. Prolonged activation of these enzymes is believed to contribute to cell death $(1,3)$.

A number of studies conducted on hepatocytes, and some on myocardial cells, suggest that cell injury due to thiol depletion results from the consequent elevation of intracellular $\mathrm{Ca}^{2+}(1,2,25)$. However, there is equally persuasive evidence to suggest 
that thiol depletion alone may cause cell death, by a $\mathrm{Ca}^{2+}$-independent mechanism, through resultant oxidative damage $(16,17)$. Although lethal cell injury accompanying oxidative stress is associated with elevation in cytosolic free $\mathrm{Ca}^{2+}$, the loss of cell viability may not result from the observed changes in intracellular $\mathrm{Ca}^{2+}$ levels (32). The loss of GSH as an antioxidant may play a more important role in loss of cell viability, through oxidative damage, and the resultant lipid peroxidation $(3,21)$.

In this study our approach towards this problem was to create a model of oxidative stress, using ethacrynic acid (EA), a selective sulfhydryl alkylating agent $(3,40,41)$, to deplete intracellular thiols. This model permitted us to examine the key biochemical events affected by thiol depletion, including perturbations of $\mathrm{Ca}^{2+}$ homeostasis, and the contribution of these events to cell death. A major goal of this study was directed towards attempting to elucidate the role of thiol status in chemically-induced lethal cell injury and to determine the relative importance of elevated intracellular $\mathrm{Ca}^{2}$ levels and oxidative stress to cell death. 


\section{METHODS}

Cardiomyocyte Isolation and Culturing. Myocardial cells were isolated and cultured essentially according to the method of Bollon et al (26) with several modifications aimed at increasing the yield of beating myocytes over that of non-muscle cells (27-29). Cells were plated in separate $35 \mathrm{~mm}$ culture dishes, incubated in Eagles MEM medium buffered with $25 \mathrm{mM}$ Hepes, $\mathrm{pH} 7.4$ and containing $10 \%$ horse serum, 5\% fetal bovine serum, 100 $\mathrm{U} / \mathrm{mL}$ penicillin, $100 \mu \mathrm{g} / \mathrm{mL}$ streptomycin and $1 \mathrm{U} / \mathrm{mL}$ insulin at $37^{\circ} \mathrm{C}$ and $95 \%$ humidity . Cells were used on the eighth day after initial plating. Beating rate provides an indicator of the quality of preparations. Cells used throughout this study had an average beating rate of between $140-160$ beats/min .

General Conditions for Exposure to Chemicals and Solvents. Cells were rinsed twice with Hank's balanced salt solution containing $25 \mathrm{mM}$ Hepes, $\mathrm{pH} 7.4$, and incubated at $37^{\circ} \mathrm{C}$ with $150 \mu \mathrm{M} \mathrm{EA}$, in the absence or presence of $5 \mu \mathrm{M} \mathrm{N}, N^{\prime}-$ Diphenyl-pphenylenediamine (DPPD), $120 \mu \mathrm{M}$ EGTA-acetoxymethylester (EGTA-AM) or $120 \mu \mathrm{M}$ Quin-2-acetoxymethylester (Quin-2-AM) for the stipulated incubation time (7-240 minutes). Appropriate solvent controls were conducted for all experimental conditions. Solvent controls for all EA incubations contained $0.3 \%(v / v)$ ethanol. Controls for cells treated with DPPD contained $0.5 \%(\mathrm{v} / \mathrm{v})$ DMSO, in addition to $0.3 \%$ ethanol. For studies using Quin-2-AM or EGTA-AM, the cells were preincubated with $120 \mu \mathrm{M}$ Quin-2-AM or $120 \mu \mathrm{M}$ EGTA-AM, dissolved in DMSO $(0.4-0.6 \%, v / v)$ for $45 \mathrm{~min}$ at $37^{\circ} \mathrm{C}$. At the end of incubation time the plates were rinsed twice with Hank's balanced salt solution and incubated in the presence or absence of $150 \mu \mathrm{M}$ EA for the appropriate time. Controls for Quin-2-AM or EGTA-AM were preincubated with $0.4-0.6 \%$ DMSO $(v / v)$, then incubated in the presence or absence of EA. At the end of the incubation time, the incubation solutions were removed from the plates and retained for use in the biochemical 
determinations mentioned below. Adherent myocardial cells were lysed with lysing buffer containing $100 \mathrm{mM} \mathrm{NaF,} 20 \mathrm{mM}$ EDTA, $50 \mathrm{mM}$ glycylglycine, $0.5 \%$ Triton $\mathrm{x}-100$, and $0.5 \%$ glycogen, $\mathrm{pH} 7.4$, according to the procedure of Long and Moore (30). Cells were scraped from plates, centrifuged at $13,500 \mathrm{~g}$ for 5 minutes, and the resultant supernatant, termed cell lysate, was removed and reserved to obtain the following biochemical measurements.

\section{Biochemical Assays.}

Lactate Dehydrogenase ( $L D H)$ Activity. LDH leakage into the incubation medium was used as an indicator of cell death. LDH activity was measured by monitoring the disappearance of $\mathrm{NADH}$ at $340 \mathrm{~nm}$, spectrophotometrically by the method of Lindstrom et al (31) and expressed as a percentage of total cellular LDH .

Phosphorylase a Assay. The $\mathrm{Ca}^{2+}$-dependent conversion of phosphorylase $b$ to phosphorylase $a$ was used as an indirect estimate of intracellular free $\mathrm{Ca}^{2+}$. Phosphorylase $a$ was determined by measuring the Pi released from glucose-1-phosphate, by the method of Gilboe et al (33), as modified by Farber et al (32).

Phosphatidylinositide Hydrolysis. An alternate indirect measurement of intracellular $\mathrm{Ca}^{2+}$ was conducted by measuring the phosphatidylinositide hydrolysis by $\mathrm{Ca}^{2+}$-activated phospholipase $c$. The assay procedure of Slivka et al (34) was followed. Cellular phosphatidylinositide was radioabeled by the incorporation of $2 \mu \mathrm{Ci} / \mathrm{mL}$ of [2- $\left.{ }^{3} \mathrm{H}\right]-m y o-i n o s i t o l$ for $24 \mathrm{hr}$ at $37^{\circ} \mathrm{C}$. Following various chemical exposures, the cells were precipitated with $10 \%$ trichloroacetic acid (TCA) and the resultant supernatant were analyzed for the radiolabel released into the medium. The pellets were solubilised in $5 \mathrm{ml}$ scintillation fluid and analyzed for the radiolabel retained. Results were expressed as the percent of total $\left[2-{ }^{3} \mathrm{H}\right]-$ myo-inositol hydrolysed.

Protein Thiol and GSH Analyses. The original method of Sedlak and Lindsay (35), as 
modified by Orrenius et al (36) was followed. Briefly, cell incubate was removed and plates were treated with $6.5 \%$ TCA, scraped and centrifuged at low speed, and the resultant supernatants analyzed for GSH levels by the HPLC method of Reed et al (37). To estimate protein thiols, the pellet was washed twice with $6.5 \%$ TCA and suspended in $0.5 \mathrm{M}$ Tris- $\mathrm{HCl}$ containing $100 \mu \mathrm{M}$ 5,5'-dithio-bis-(2-nitrobenzoic acid) (DTNB), pH 8.3, and the absorbance read at $412 \mathrm{~nm}$. Results were expressed as nanomoles SH/mg protein. Lipid Peroxidation Assay. Lipid peroxidation was measured by monitoring the formation of a colored complex between malondialdehyde and thiobarbituric acid (TBA), by the method of Stacey and Klaassen (38) as modified by Thomas and Reed (17). Briefly, at the end of incubation $100 \%$ TCA was added to the cells to a final concentration of $12 \%$, and the cell suspension was treated with $0.67 \%$ thiobarbituric acid for 20 minutes at $90^{\circ} \mathrm{C}$. TBA-reactants formed were measured at $532 \mathrm{~nm}$. Results were expressed in terms of percent of EA-treated cell values.

Mitochondrial Membrane Potential. The distribution of $\left[{ }^{3} \mathrm{H}\right]$-triphenylmethylphosphonium ion (TPMP) between the cardiomyocytes and the incubation solutions was used to determine the collapse of mitochondrial membrane potential. Changes in mitochondrial membrane potential were monitored according to the procedure of Hoeke et al (23). Cells were radiolabeled by incubation with $0.25 \mu \mathrm{Ci} / \mathrm{ml}$ of $\left[{ }^{3} \mathrm{H}\right]-\mathrm{TPMP}$ for $1 \mathrm{hr}$ at $37^{\circ} \mathrm{C}$. At end of incubation cells were exposed to $150 \mu \mathrm{M} \mathrm{EA}$ or solvent control for 30-75 min. The results were expressed as percent $\left[{ }^{3} \mathrm{H}\right]$-TPMP released into the culture medium at the end of incubation time.

Measurement of ATP. Following various chemical exposures, ATP levels of cell lysates were determined using the luciferin-luciferase bioluminescent method of Wulf and Doppen (39).

Glyceraldehyde 3-phosphate Dehydrogenase Activity. Myocyte glyceraldehyde 3-phosphate dehydrogenase activity was measured by monitoring the conversion of 
3-phosphoglycerol phosphate and NADH to D glyceraldehyde-3-phosphate and $\mathrm{NAD}^{+}$, spectrophotometrically according to the method of Birkett et al (13).

Protein Estimation. Certain data as mentioned in the methods was normalized on the basis of per mg protein. All protein values were obtained by the Bradford protein assay (44). STATISTICAL ANALYSIS: All data were summarized as the mean \pm SD. Significance of the difference between the groups was determined by the 2-tailed Student's t-test. 


\section{RESULTS}

$\mathrm{LDH}$ leakage was used as criterion for assessing the loss of cell viability. As shown in Fig. 1, incubation of cells for $4 \mathrm{hr}$ with increasing concentrations of EA ( $50-150 \mu \mathrm{M})$ demonstrated a concentration-dependent increase in LDH leakage. There was a concentration-dependent increase in LDH leakage, 57, 78 and $83 \%$ with 50,100 and 150 $\mu \mathrm{M}$ EA, respectively. There was no significant LDH leakage $(6 \%)$ in the solvent control even after $4 \mathrm{hr}$. Further studies conducted with $150 \mu \mathrm{M}$ EA for varying amounts of incubation time (7-240 $\mathrm{min}$ ), exhibited a time-dependent increase in LDH leakage (Fig. 2). LDH leakage was significantly different from the solvent control only after $90 \mathrm{~min}$ and beyond, thus permitting us to examine the key biochemical events preceding cell death. At the end of $4 \mathrm{hr}$ incubation, cells treated with $150 \mu \mathrm{M}$ EA showed $82 \%$ leakage as compared to only $7 \%$ for the vehicle control.

The results in Fig. 3 show that there was a rapid depletion of intracellular GSH levels in cells treated with $150 \mu \mathrm{M}$ EA. GSH dropped rapidly to $50 \%$ of the control levels at 7 min and to less than $1 \%$ of controls by $60 \mathrm{~min}$. The status of intracellular protein thiols in the face of an EA challenge was examined over the same time period and illustrated in Fig. 4. We observed a time-dependent depletion in protein thiols, which corresponds to $32 \%$ of the control values at 60 minutes. Our data suggests that in EA-induced myocardial cell injury, a significant decrease in GSH precedes the depletion of intracellular protein thiols, and both these events occur well before the onset of LDH leakage is observed.

Intracellular $\mathrm{Ca}^{2+}$ levels were monitored by measurement of the $\mathrm{Ca}^{2+}$-dependent conversion of phosphorylase $b$ to phosphorylase $a$. As shown in Fig. 5, there was a time-dependent increase in phosphorylase $a$ activity when the cells were treated with 150 $\mu \mathrm{M}$ EA. The elevation of phosphorylase $a$ activity, expressed as nmoles $\mathrm{Pi} / \mathrm{min} \cdot \mathrm{mg}$ protein, reached a maximum at $60 \mathrm{~min}$ and the value was $124 \pm 43$ as compared to $18 \pm 11$ for the controls. This indicates that EA-induced increase in intracellular $\mathrm{Ca}^{2+}$ reached a 
maximum by $60 \mathrm{~min}$. Again, as with thiol depletion this maximum was reached well before $\mathrm{LDH}$ leakage was observed.

The intracellular $\mathrm{Ca}^{2+}$ chelators, Quin-2-AM and EGTA-AM were used to assess the importance of EA-induced $\mathrm{Ca}^{2+}$ increase in cell injury. These specific intracellular $\mathrm{Ca}^{2+}$ chelators were used to attempt buffering the rise in intracellular $\mathrm{Ca}^{2+}$ levels, and their effect on subsequent cell injury. Results show $\mathrm{LDH}$ leakage after $2 \mathrm{hr}$ incubation with EA $(150 \mu \mathrm{M})$. Cells preincubated $45 \mathrm{~min}$ with Quin-2-AM or EGTA-AM showed leakage of $25 \pm 8 \%$ and $11 \pm 2 \%$, upon subsequent treatment with EA, respectively (Fig. 6). These data indicate that Quin-2- AM and EGTA-AM decreased LDH leakage, which was $58 \%$ at $2 \mathrm{hr}$, by 57 and $81 \%$, respectively. Pretreatment of cells with just DMSO did not alter EA toxicity ( $\mathrm{LDH}$ release, $58 \pm 5 \%$ as compared to $54 \pm 6 \%$ ). Surprisingly, while both the intracellular $\mathrm{Ca}^{2+}$ chelators reduced cell injury, they failed to reduce the magnitude of EA-induced increase in intracellular free $\mathrm{Ca}^{2+}$, based on phosphorylase $a$ activity, as shown in Fig.7. Phosphorylase $a$ activity in cells treated with $150 \mu \mathrm{M}$ EA in the presence of DMSO, at the end of $1 \mathrm{hr}$ incubation, was found to be $120 \pm 27$ nmoles $\mathrm{Pi}$ / min - mg protein. In comparison, phosphorylase $a$ activity of cells preincubated with Quin-2 AM or EGTA AM, preceding an EA challenge was found to be $129 \pm 40$ and $171 \pm$ $40 \mathrm{nmoles} \mathrm{Pi} / \mathrm{mg}$ protein.min, respectively. These values were not significantly different from the phosphorylase $a$ activity of cells treated with EA, which was $120 \pm 27$ nmoles $\mathrm{Pi}$ / $\min \cdot \mathrm{mg}$ protein at $1 \mathrm{hr}$. Furthermore, pretreatment of cells with Quin-2-AM or EGTA-AM, and in the absence of EA, did not alter the the phosphorylase $a$ activity in comparison to the DMSO control (67 \pm 21 and $68 \pm 13$, respectively as compared to $50 \pm$ 24 nmoles $\mathrm{Pi} / \mathrm{min} \cdot \mathrm{mg}$ protein at $1 \mathrm{hr}$ ). Phosphoinositide hydrolysis initiated by $\mathrm{Ca}^{2+}$-dependent phospholipase $c$ activation, was used as an alternative method to verify the observed increase in intracellular $\mathrm{Ca}^{2+}$ levels. Fig. 8 shows that phosphoinositide hydrolysis, initiated by $\mathrm{Ca}^{2+}$-dependent phospholipase $c$ activation, is $6 \%$ in the face of 
$150 \mu \mathrm{M}$ EA challenge. The intracellular $\mathrm{Ca}^{2+}$ chelators Quin-2-AM and EGTA-AM have no effect in reducing the extent of phosphoinositide hydrolysis.

Since thiol depletion is known to correlate with oxidative damage, we examined whether EA-induced cell death involved peroxidative damage. Towards this end, cells were treated with $150 \mu \mathrm{M} \mathrm{EA}$, in the presence or absence of the antioxidant DPPD $(5 \mu \mathrm{M})$, then examined for cell viability at the end of $2 \mathrm{hr}$ incubation. Our results, illustrated in Fig. 9 , show that $5 \mu \mathrm{M}$ DPPD was capable of reducing damage by $89 \%$ for cells treated with $150 \mu \mathrm{M} \mathrm{EA}$, as measured by LDH leakage. DPPD treated cells showed $7 \pm 1 \%$ leakage as compared to $61 \pm 5 \%$ for EA treated cells. The solvent control for DPPD showed no significant amount of leakage at $2 \mathrm{hr}$. We also assessed the role of DPPD on elevated intracellular $\mathrm{Ca}^{2+}$ levels monitored by $\mathrm{Ca}^{2+}$-dependent activation of phosphorylase $a$. Fig. 10 , shows that DPPD had no effect in reducing the elevated levels of intracellular $\mathrm{Ca}^{2+}$ in the presence of $150 \mu \mathrm{M}$ ethacrynic acid. No changes in phosphorylase $a$ activity was observed in the appropriate controls $(65 \pm 13 \mathrm{nmoles} \mathrm{Pi} / \mathrm{min} \cdot \mathrm{mg}$ protein for DMSO and $60 \pm 9 \mathrm{nmoles} \mathrm{Pi} / \mathrm{min} \cdot \mathrm{mg}$ protein for DPPD) suggesting that there was no interference in our assay by solvents employed. Furthermore, $5 \mu \mathrm{M}$ DPPD had no effect on EA-induced depletion of intracellular GSH levels (Table 1).

These observations led us to examine whether EA-induced thiol depletion in myocardial cells led to peroxidative damage. Fig. 11 shows that the antioxidant DPPD, and surprisingly the intracellular $\mathrm{Ca}^{2+}$ chelators Quin-2-AM and EGTA-AM, markedly reduced lipid peroxidation, as monitored by the absorbance at $532 \mathrm{~nm}$ of 2-thiobarbiturate reaction products. DPPD $(5 \mu \mathrm{M})$, Quin-2-AM $(120 \mu \mathrm{M})$, and EGTA-AM $(120 \mu \mathrm{M})$ significantly reduced lipid peroxidation by $90 \%, 60 \%$, and $62 \%$, respectively.

The possibility that EA-induced cell injury involved impairment of cellular energy status was assessed by examining the integrity of mitochondrial membrane potential and cellular ATP levels as biochemical indices.Changes in mitochondrial membrane potential 
were expressed as the percent $\left[{ }^{3} \mathrm{H}\right]$-TPMP released into the culture medium. Results of previous studies have observed that $90 \%$ of $\left[{ }^{3} \mathrm{H}\right]$-TPMP is localized in the mitochondria, and the total cellular content closely corresponds to changes in mitochondrial membrane potential (32). Fig. 12, shows the results of various chemical exposures on the mitochondrial membrane potential, for varying periods of time ranging from 30-75 $\mathrm{min}$. The cells treated with $150 \mu \mathrm{M}$ EA did not vary significantly from the solvent control values even at $75 \mathrm{~min}$. As a positive control, cells were exposed to an uncoupler of oxidative phosphorylation, CCCP $(25 \mu \mathrm{M})$. A rapid collapse of mitochondrial membrane potential was observed ( $24 \pm 1 \%$ at $30 \mathrm{~min}$ and $14 \pm 3 \%$ at $75 \mathrm{~min}$ ). ATP levels in the cell lysates were determined for cells treated with $150 \mu \mathrm{M} \mathrm{EA}$ over a time range of $7-75 \mathrm{~min}$. As shown in Table 2, the ATP values for cell treated with EA ( $46 \pm 7$ nmoles ATP/mg protein) were different from the control values at $75 \min (55 \pm 6 \mathrm{nmoles}$ ATP/mg protein).

Previous studies conducted by Birkett et al (11), have examined the effect of ethacrynic acid on the cytosolic marker enzyme glyceraldehyde 3-phosphate dehydrogenase (G3PD), and have observed irreversible alkylative damage of the protein thiol groups. Fig. 13 shows the results of our studies conducted on this marker enzyme. G3PD activity was expressed as $\mu$ moles $\mathrm{NADH} / \mathrm{min} \cdot \mathrm{mg}$ protein and measured at the end of $1 \mathrm{hr}$ incubation with various chemical exposures. Cells were treated with $150 \mu \mathrm{M} \mathrm{EA}$ in the presence or absence of $120 \mu \mathrm{M}$ Quin-2-AM, $120 \mu \mathrm{M}$ EGTA-AM or $5 \mu \mathrm{M}$ DPPD. Our studies demonstrates that ethacrynic acid diminishes the enzyme activity to $30 \%$ of the control values, whereas the intracellular $\mathrm{Ca}^{2+}$ chelator EGTA-AM, and the antioxidant DPPD had no protective effect, but surprisingly Quin-2-AM provided $88 \%$ protection to the enzyme activity. 
Figure 1. Concentration dependent effect of EA on cell viability in cultured cardiomyocytes. Myocytes were incubated at $37^{\circ} \mathrm{C}$ in the presence of a range of EA concentrations (0-150 $\mu \mathrm{M})$ in Hank's balanced salt solution containing $1.2 \mathrm{mM} \mathrm{Ca}^{2+}, 0.3 \%$ ethanol $(\mathrm{v} / \mathrm{v})$ and buffered to $\mathrm{pH} 7.4$ with $25 \mathrm{mM}$ Hepes. Cell viability was determined by leakage of $\mathrm{LDH}$ after $4 \mathrm{hr}$ incubation with EA. Values represent the mean \pm SD of duplicate assays, from 3 separate myocyte preparations. 


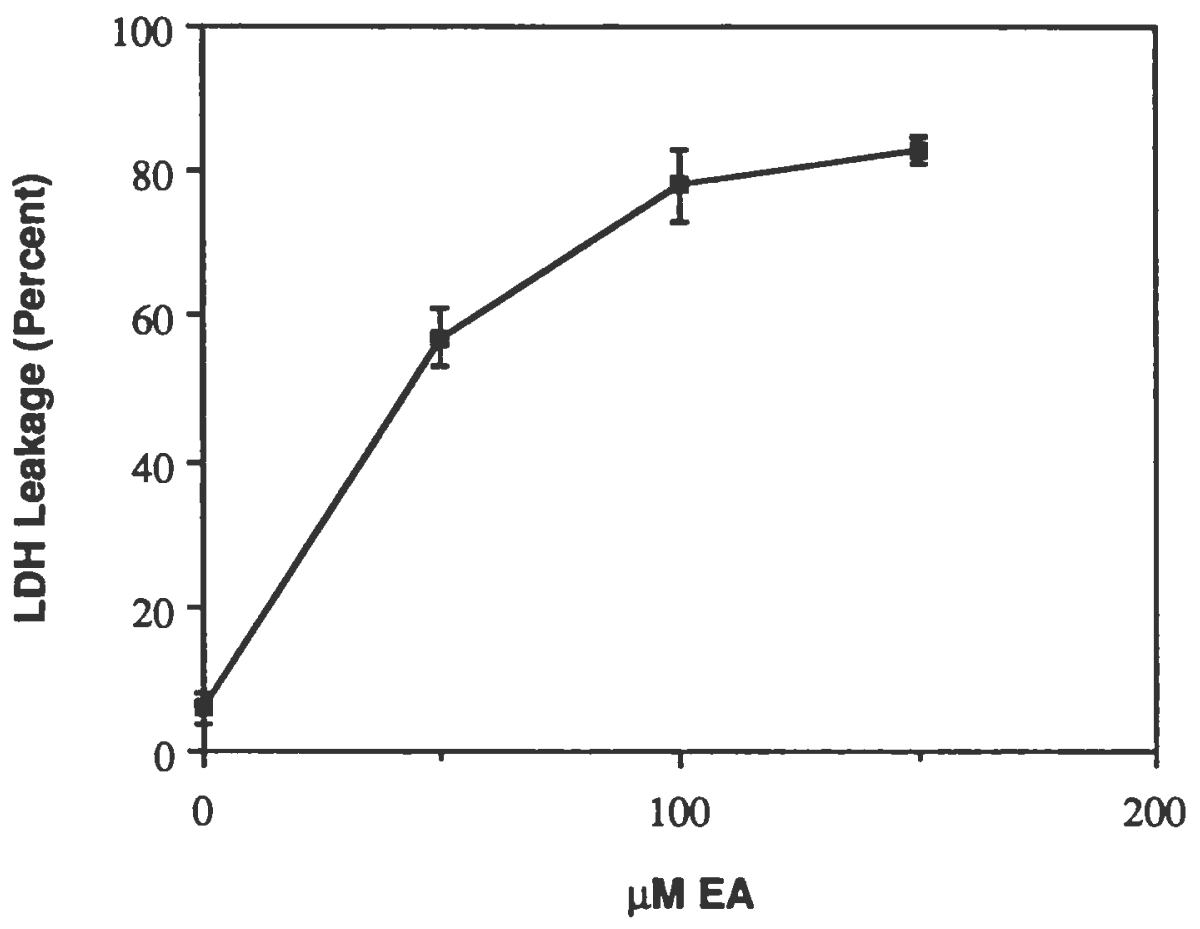


Figure 2. Time dependence of the effect of $150 \mu M E A$ on cardiomyocyte cell viability. Myocytes were incubated at $37^{\circ} \mathrm{C}$ in Hank's balanced salt solution containing1.2 $\mathrm{mM} \mathrm{Ca}^{2+}$, $0.3 \%$ ethanol (v/v) and buffered to $\mathrm{pH} 7.4$ with $25 \mathrm{mM}$ Hepes, in the absence (D) or presence $(a)$ of $150 \mu \mathrm{M}$ EA. Values represent the mean \pm SD of measurements from 3-12 separate preparations. Differences between EA and control cells were significant at $p<0.01$ $(*)$. 


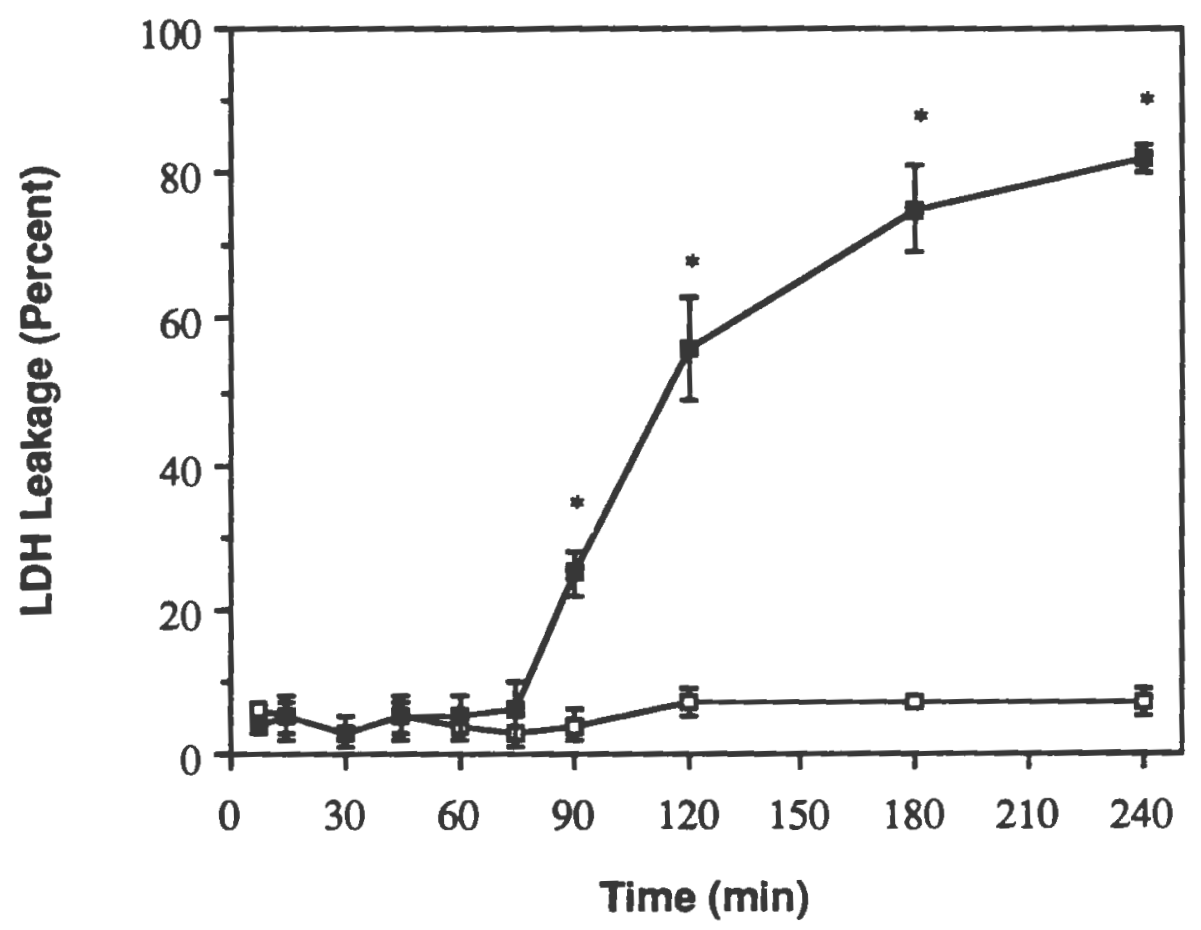


Figure 3. Time dependence of the effect of $150 \mu \mathrm{MEA}$ on cardiomyocyte glutathione (GSH) levels. Myocytes were incubated at $37^{\circ} \mathrm{C}$ in Hank's balanced salt solution containing $1.2 \mathrm{mM} \mathrm{Ca}^{2+}, 0.3 \%$ ethanol $(\mathrm{v} / \mathrm{v})$ and buffered to $\mathrm{pH} 7.4$ with $25 \mathrm{mM}$ Hepes, in the absence $(\square)$ or presence $(\square)$ of $150 \mu \mathrm{M} \mathrm{EA}$. At times indicated, GSH levels were determined by HPLC method of Reed et al (37). Values represent the mean $\pm S D$ of measurements from 3 separate myocyte preparations. Differences between EA treated cells and control cells are significant at $p<0.01\left({ }^{*}\right)$. 


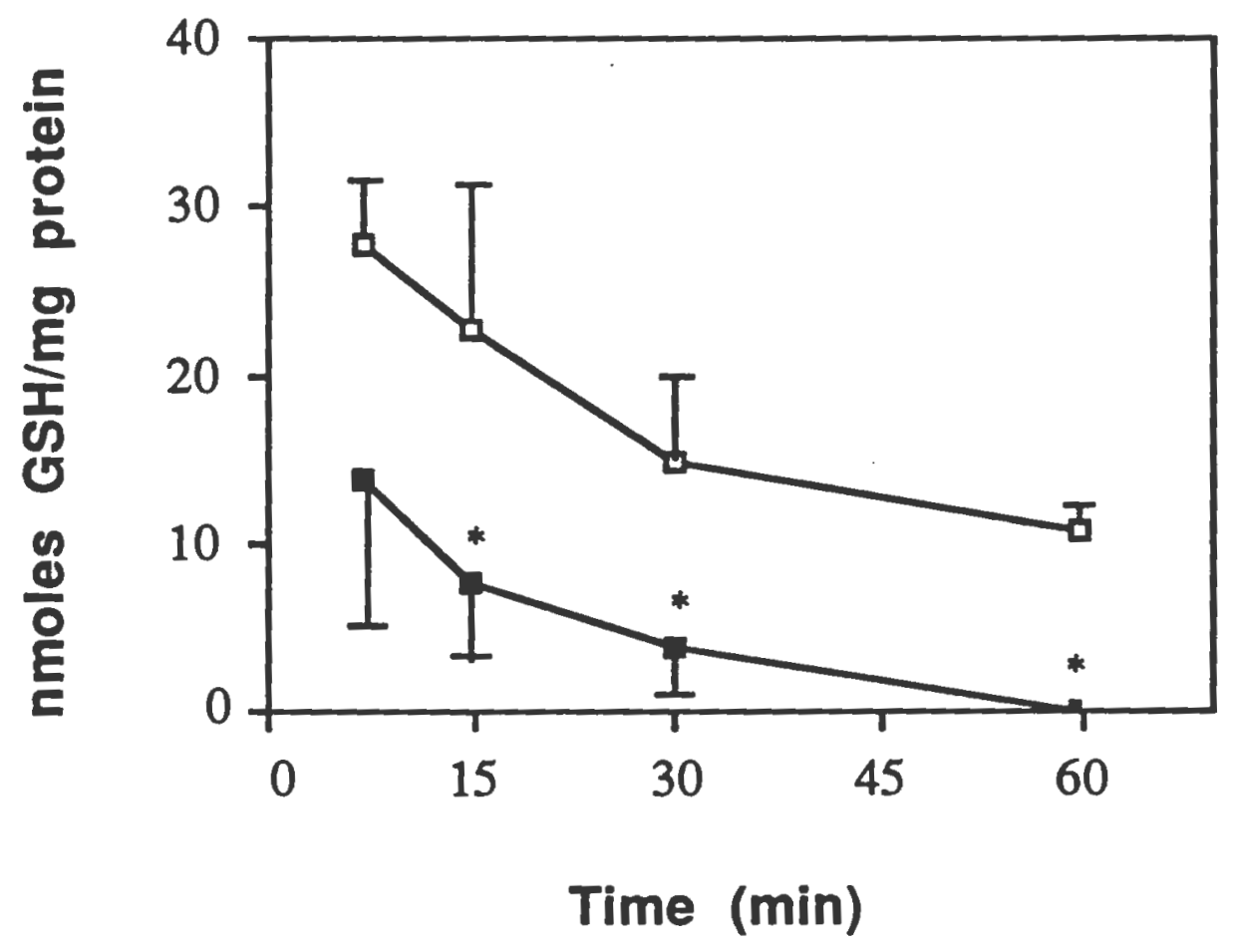


Figure 4. Time dependence of the effect of $150 \mu M$ EA on cardiomyocyte protein thiol levels. Myocytes were incubated at $37^{\circ} \mathrm{C}$ in Hank's balanced salt solution containing 1.2 $\mathrm{mM} \mathrm{Ca}{ }^{2+}, 0.3 \%$ ethanol $(\mathrm{v} / \mathrm{v})$ and buffered to $\mathrm{pH} 7.4$ with $25 \mathrm{mM}$ Hepes, in the absence (ㅁ) or presence ( () of $150 \mu \mathrm{M} \mathrm{EA}$. At times indicated the content of myocyte protein thiols was determined. Values represent the mean \pm SD of measurements from 7 separate myocyte separations. Differences between EA treated cells and control cells are significant at $p<0.05$ $(*)$ and $\mathrm{p}<0.01(* *)$. 


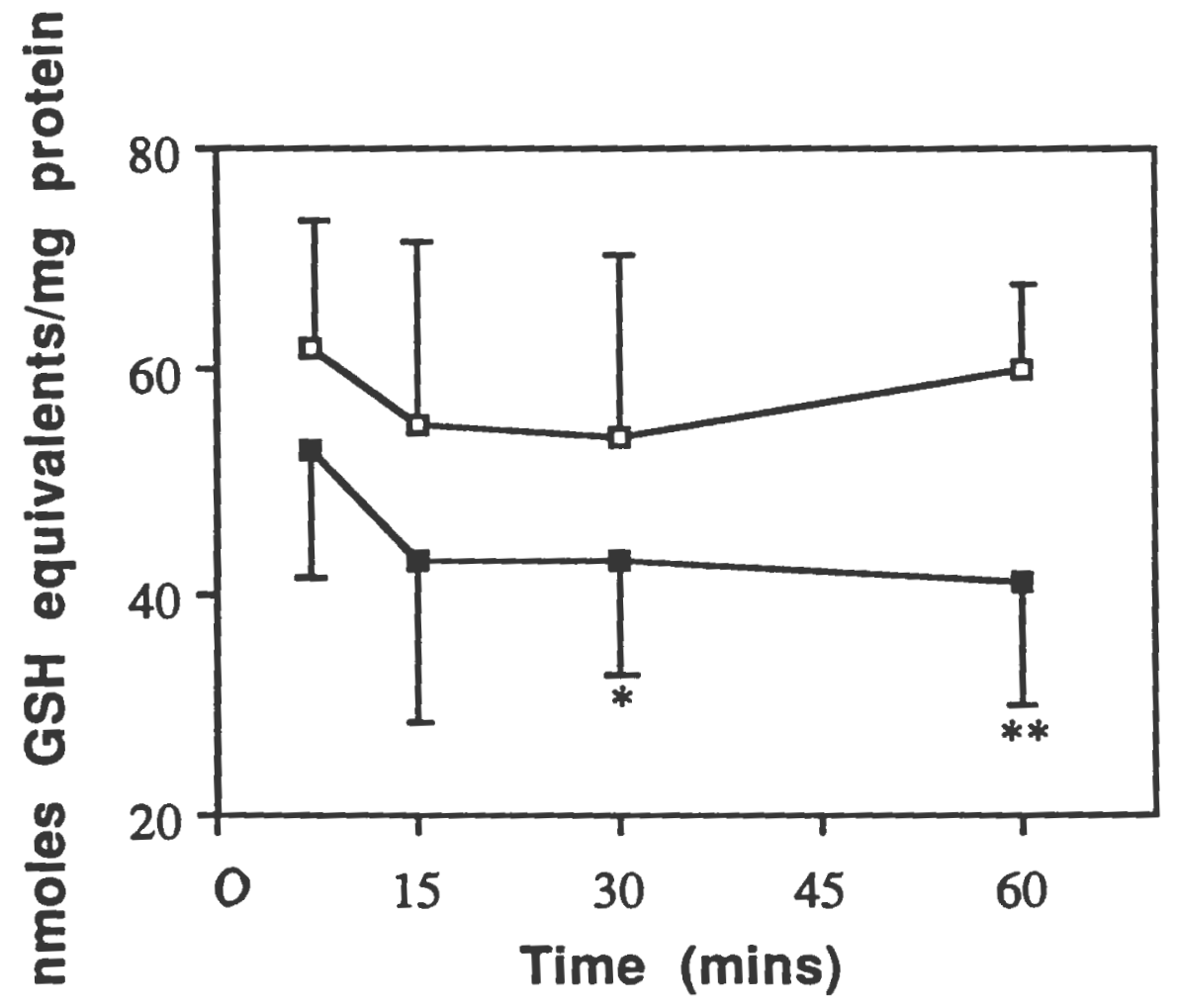


Figure 5. Time dependence of the effect of $150 \mu M$ EA on cardiomyocyte phosphorylase a activity. Myocytes were incubated at $37^{\circ} \mathrm{C}$ in Hank's balanced salt solution containing 1.2 $\mathrm{mM} \mathrm{Ca}{ }^{2+}, 0.3 \%$ ethanol $(\mathrm{v} / \mathrm{v})$ and buffered to $\mathrm{pH} 7.4$ with $25 \mathrm{mM}$ Hepes, in the absence (a) or presence ( $\square$ ) of $150 \mu \mathrm{M} \mathrm{EA}$. At times indicated the phosphorylase $a$ activity was determined. Values represent the mean $\pm S D$, at $7,15,45$, and $75 \min (n=3)$, at $30 \mathrm{~min}$ ( $n$ $=6$ ), and at $60 \min (n=9)$. Differences between EA treated cells and control cells are significant at $\mathrm{p}<0.01\left(^{*}\right)$. 


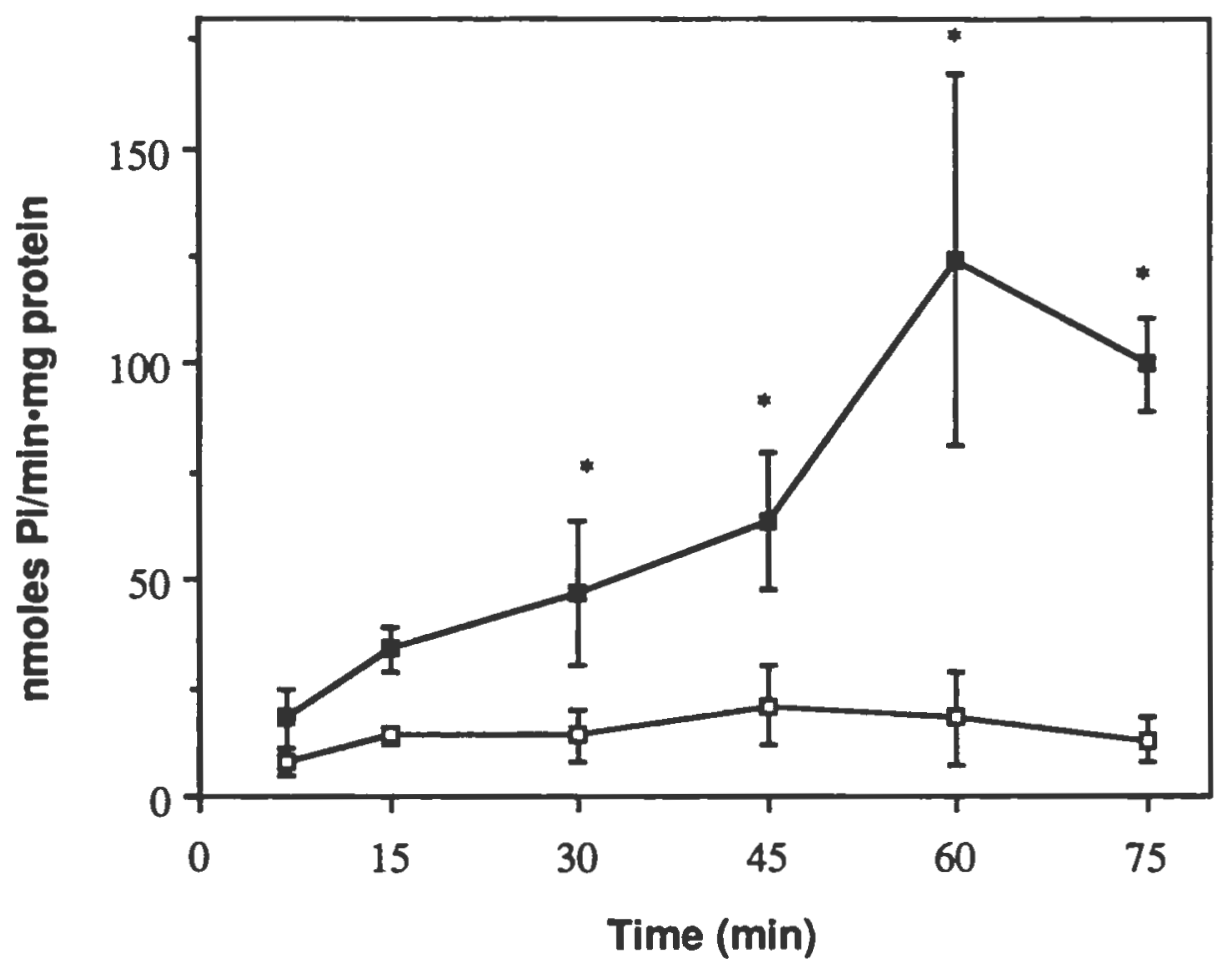


Figure 6. Effect of intracellular $\mathrm{Ca}^{2+}$ chelators, Quin-2 -AM and EGTA-AM, on EA-induced cell injury in cultured cardiomyocytes. Cardiomyocytes were preincubated with $120 \mu \mathrm{M}$ Quin-2-AM, EGTA-AM, or 0.5\% DMSO ( $v / v)$ for $45 \mathrm{~min}$. At that time the myocyte cultures were rinsed twice with Hank's balanced salt solution $\left(1.2 \mathrm{mM} \mathrm{Ca}^{2+}\right)$ containing $25 \mathrm{mM}$ Hepes, $\mathrm{pH} 7.4$ at $37^{\circ} \mathrm{C}$. Myocytes were then incubated in Hank's balanced salt solution, $0.3 \%$ ethanol, in the absence (D) or presence ( $($ ) of $150 \mu \mathrm{M} \mathrm{EA}$. At the end of $2 \mathrm{hr}$ incubation, cell viability was determined based on the leakage of LDH. Values represent the mean \pm SD of 3-7 separate cardiomyocyte preparations. Differences between EA treated cells and control cells, in the absence or presence of EGTA-AM and Quin-2-AM are significant at $\mathrm{p}<0.01(*)$. 


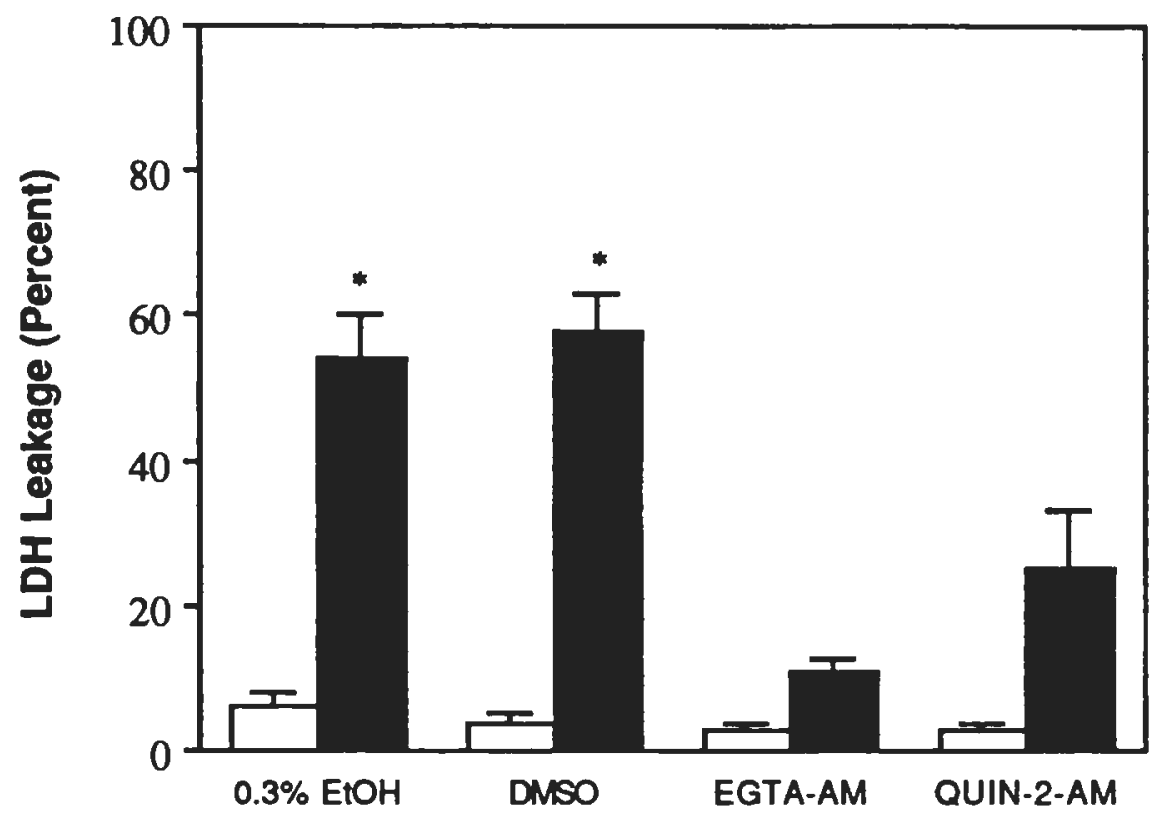


Figure 7. Effect of intracellular $\mathrm{Ca}^{2+}$ chelators, Quin-2 -AM and EGTA-AM, on EA-induced increase of phosphorylase a activity in cultured cardiomyocytes. Cardiomyocytes were preincubated with $120 \mu \mathrm{M}$ Quin-2-AM or EGTA-AM or $0.5 \%$ DMSO (v/v) for $45 \mathrm{~min}$. Cultures were rinsed twice with Hank's balanced salt solution $\left(1.2 \mathrm{mM} \mathrm{Ca}^{2+}\right)$ containing 25 $\mathrm{mM}$ Hepes, $\mathrm{pH}$ 7.4. Myocytes were then incubated in Hank's balanced salt solution, $0.3 \%$ ethanol, in the absence (D) or presence ( $\square$ ) of $150 \mu \mathrm{M} \mathrm{EA}$. At the end of $1 \mathrm{hr}$ incubation at $37^{\circ} \mathrm{C}$ the myocyte phosphorylase $a$ activity was determined. Values represent the mean $\pm S D$ of 3-7 separate cardiomyocyte preparations. Differences between EA treated cells and controls cells are significant at $p<0.01\left({ }^{*}\right)$, but there is no significant difference between cells treated with and without EGTA-AM and Quin-2-AM. 


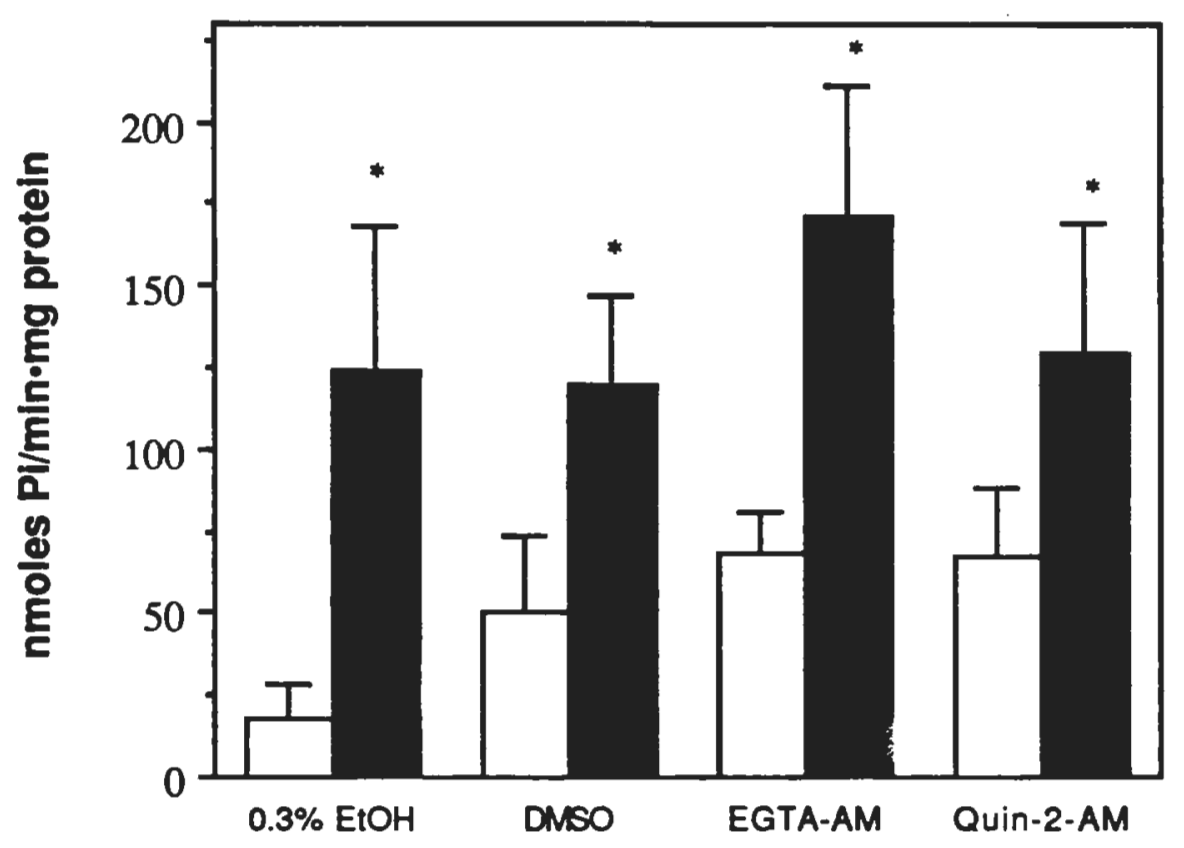


Figure 8. Effect of intracellular $\mathrm{Ca}^{2+}$ chelators, EGTA-AM and Quin-2-AM, and antioxidant DPPD on EA-induced phosphoinositide hydrolysis by $\mathrm{Ca}^{2+}$-activated phospholipase c. Cells were radiolabelled by the incorpration of $2 \mu \mathrm{Ci} / \mathrm{ml}$ of $\left[2-{ }^{3} \mathrm{H}\right]-m y o$-inositol for $24 \mathrm{hr}$ at $37^{\circ} \mathrm{C}$. At that time radiolabelled media was removed and cardiomyocytes were preincubated with $120 \mu \mathrm{M}$ Quin-2-AM, EGTA-AM or 0.5\% DMSO $(v / v)$ for 45 min. At that time cells were rinsed twice with Hank's balanced salt solution $\left(1.2 \mathrm{mM} \mathrm{Ca}^{2+}\right.$ ) containing $25 \mathrm{mM}$ Hepes, $\mathrm{pH} 7.4$ at $37^{\circ} \mathrm{C}$. Myocytes were then incubated in Hank's balanced salt solution, $0.3 \%$ ethanol, at $37^{\circ} \mathrm{C}$ for $1 \mathrm{hr}$, in the absence or presence of $150 \mu \mathrm{M}$ EA . Results were expressed as the difference between control and EA values. Separate cardiomyocyte preparations were also treated with $5 \mu \mathrm{M}$ DPPD concurrently with or without $150 \mu \mathrm{M} \mathrm{EA}$, in Hank's balance salt solution, $0.3 \%$ ethanol $(\mathrm{v} / \mathrm{v})$ and $0.4 \%$ DMSO $(\mathrm{v} / \mathrm{v})$. Values represent the mean \pm sd of of measurements from 4 separate myocyte preparations. There was no significant difference between cells treated with or without EGTA-AM, Quin-2-AM, or DPPD. 


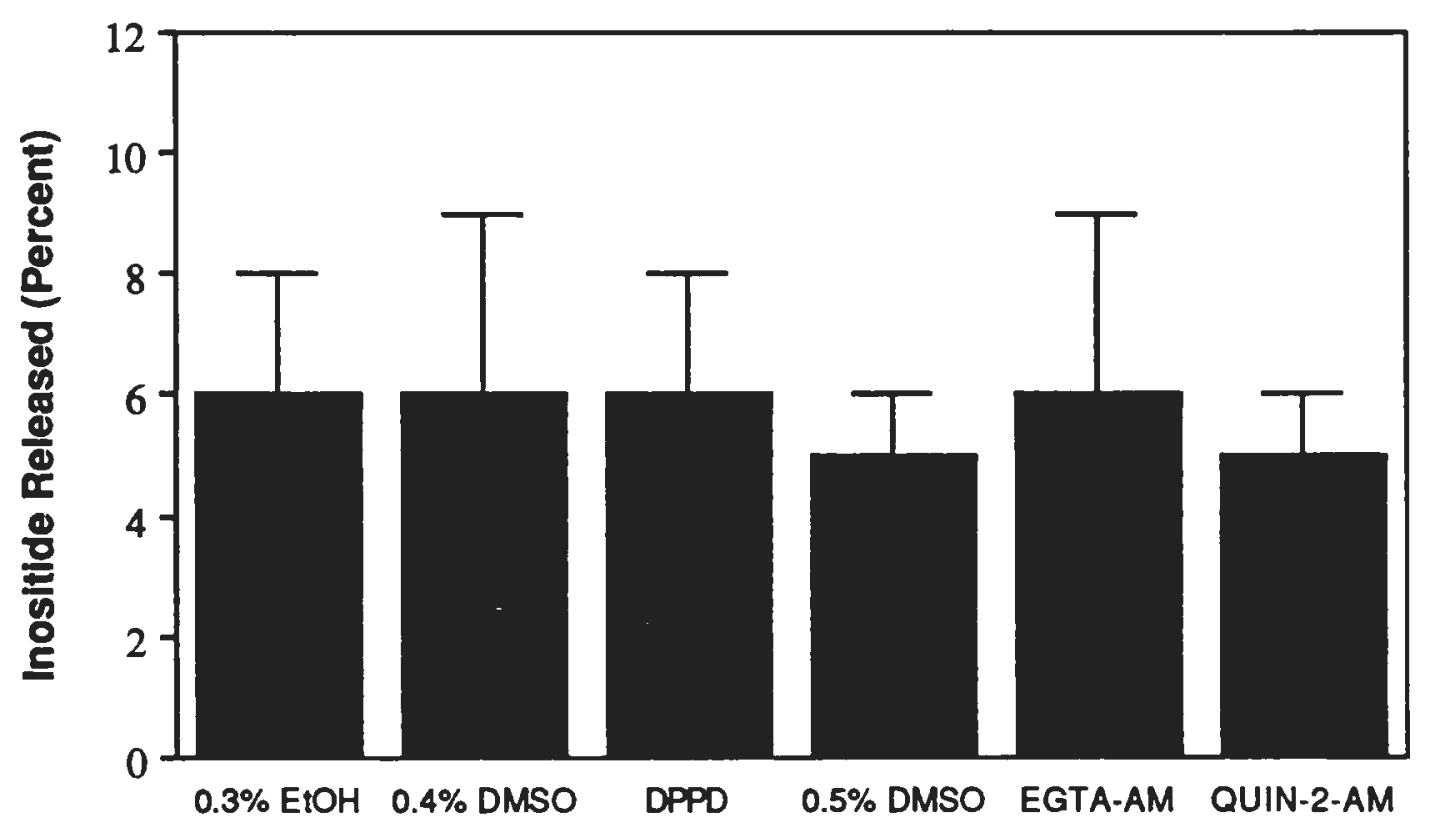


Figure 9. Effect of antioxidant DPPD, on EA-induced cell injury in cultured cardiomyocytes. Myocytes were incubated in Hank's balanced salt solution containing1.2 $\mathrm{mM} \mathrm{Ca}{ }^{2+}, 0.3 \%$ ethanol $(\mathrm{v} / \mathrm{v})$, or $0.3 \%$ ethanol $(\mathrm{v} / \mathrm{v})$ and $0.5 \%$ DMSO $(\mathrm{v} / \mathrm{v})$, and buffered to $\mathrm{pH} 7.4$ with $25 \mathrm{mM}$ Hepes at $37^{\circ} \mathrm{C}$, in the absence $(\square)$ or presence $(\omega)$ of $150 \mu \mathrm{M} \mathrm{EA}$, with or without $5 \mu \mathrm{M}$ DPPD. At the end of $2 \mathrm{hr}$ incubation at $37^{\circ} \mathrm{C}$ cell viability was determined based on the leakage of $\mathrm{LDH}$. Values represent the mean \pm sd of 4-9 separate cardiomyocyte preparations. Differences between EA treatments with and without DPPD are significant at $\mathrm{p}<0.01\left({ }^{*}\right)$. 


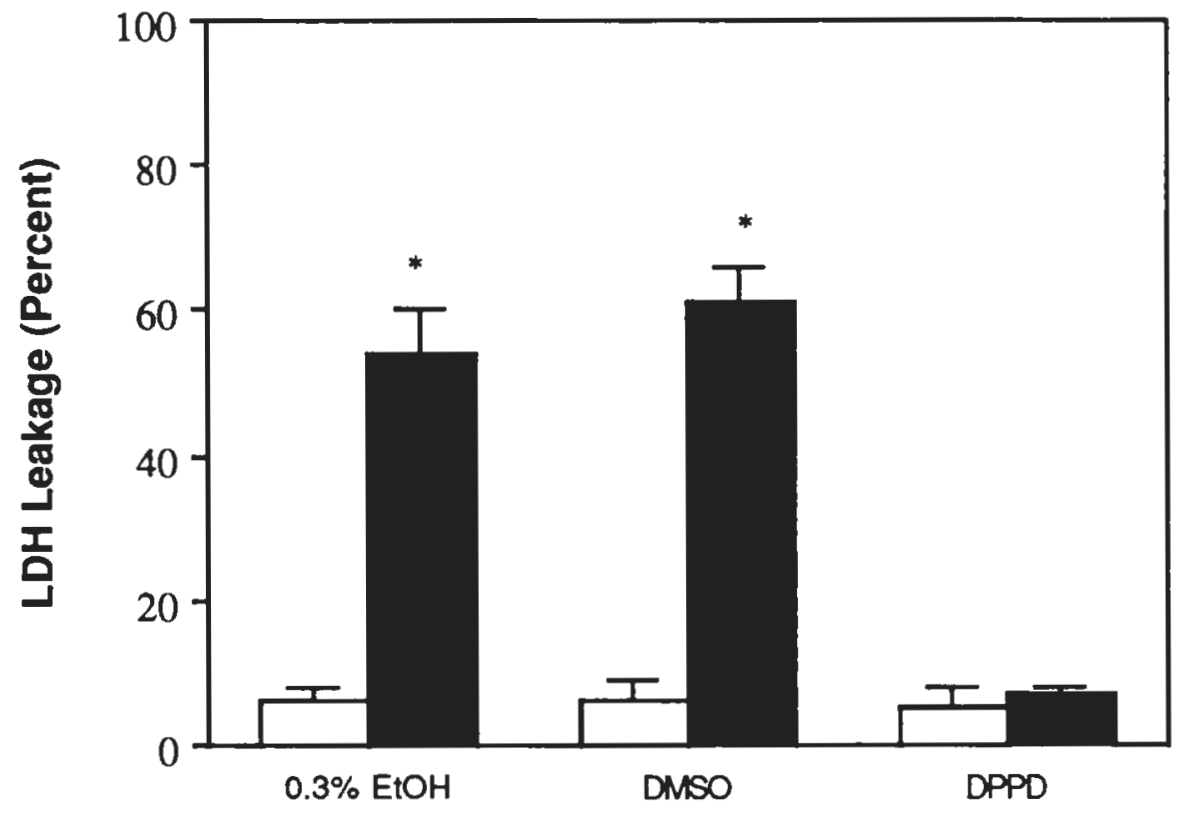


Figure 10. Effect of antioxidant DPPD, on EA-induced increase of phosphorylase a activity in cultured cardiomyocytes. Myocytes were incubated at $37^{\circ} \mathrm{C}$ in Hank's balanced salt solution containing $1.2 \mathrm{mM} \mathrm{Ca}^{2+}, 0.3 \%$ ethanol (v/v), or $0.3 \%$ ethanol $(\mathrm{v} / \mathrm{v})$ and $0.5 \%$ DMSO $(\mathrm{v} / \mathrm{v})$, and buffered to $\mathrm{pH} 7.4$ with $25 \mathrm{mM}$ Hepes, in the absence (ㅁ) or presence ( $\boldsymbol{\omega})$ of $150 \mu \mathrm{M} \mathrm{EA}$. At the end of $1 \mathrm{hr}$ incubation at $37^{\circ} \mathrm{C}$ the myocyte phosphorylase $a$ activity was determined. Values represent the mean \pm SD of 4 separate cardiomyocyte preparations. Differences between EA treated cells and controls cells are significant at $p<0.01(*)$, but there is no significant difference between cells treated with and without DPPD. 


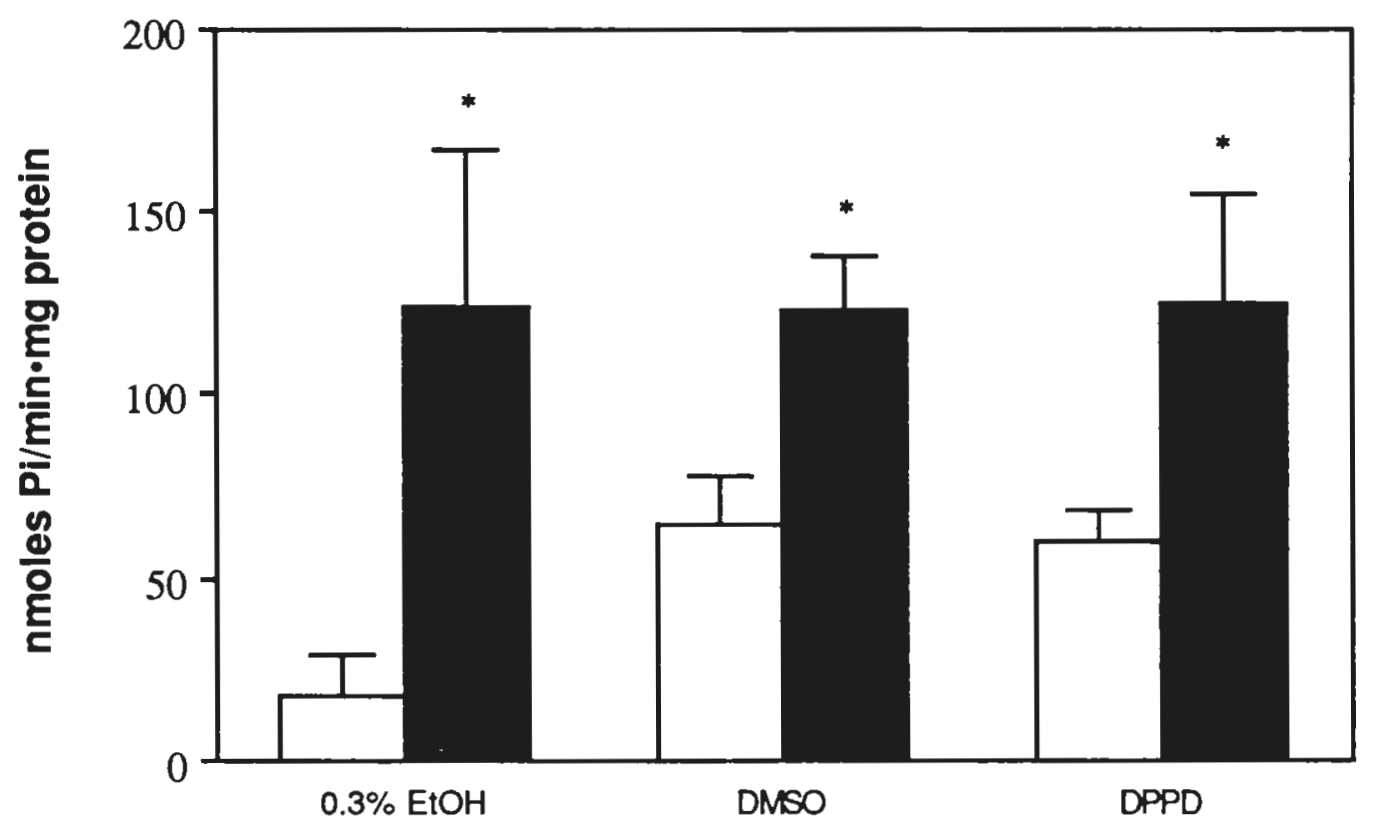


Figure 11. Lipid peroxidation in cardiomyocytes. Cardiomyocytes were preincubated with $120 \mu \mathrm{M}$ Quin-2-AM, EGTA-AM for $45 \mathrm{~min}$. At that time cultures were rinsed twice with Hank's balanced salt solution containing $1.2 \mathrm{mM} \mathrm{Ca}^{2+}$ and buffered to $\mathrm{pH} 7.4$ with $25 \mathrm{mM}$ Hepes. Myocytes were then incubated in the absence (ㅁ) or presence ( $\square$ ) of $150 \mu \mathrm{M}$ EA in Hank's balanced salt solution, $0.3 \%$ ethanol, at $37^{\circ} \mathrm{C}$ for $4 \mathrm{hr}$. Separate cardiomyocyte preparations were also concurrently treated with $5 \mu \mathrm{M}$ DPPD in Hank's balance salt solution, $0.3 \%$ ethanol $(\mathrm{v} / \mathrm{v})$ and $0.4 \%$ DMSO $(\mathrm{v} / \mathrm{v})$, with or without $150 \mu \mathrm{M} \mathrm{EA}$. TBA reactants were measured at the end of $4 \mathrm{hr}$ incubation. Values represent the mean \pm SD of 4 separate myocyte preparations. Differences between EA treated cells and control cells, and cells with or without EGTA-AM, Quin-2-AM, and DPPD, are significant at $\mathrm{p}<0.01\left(^{*}\right)$. 


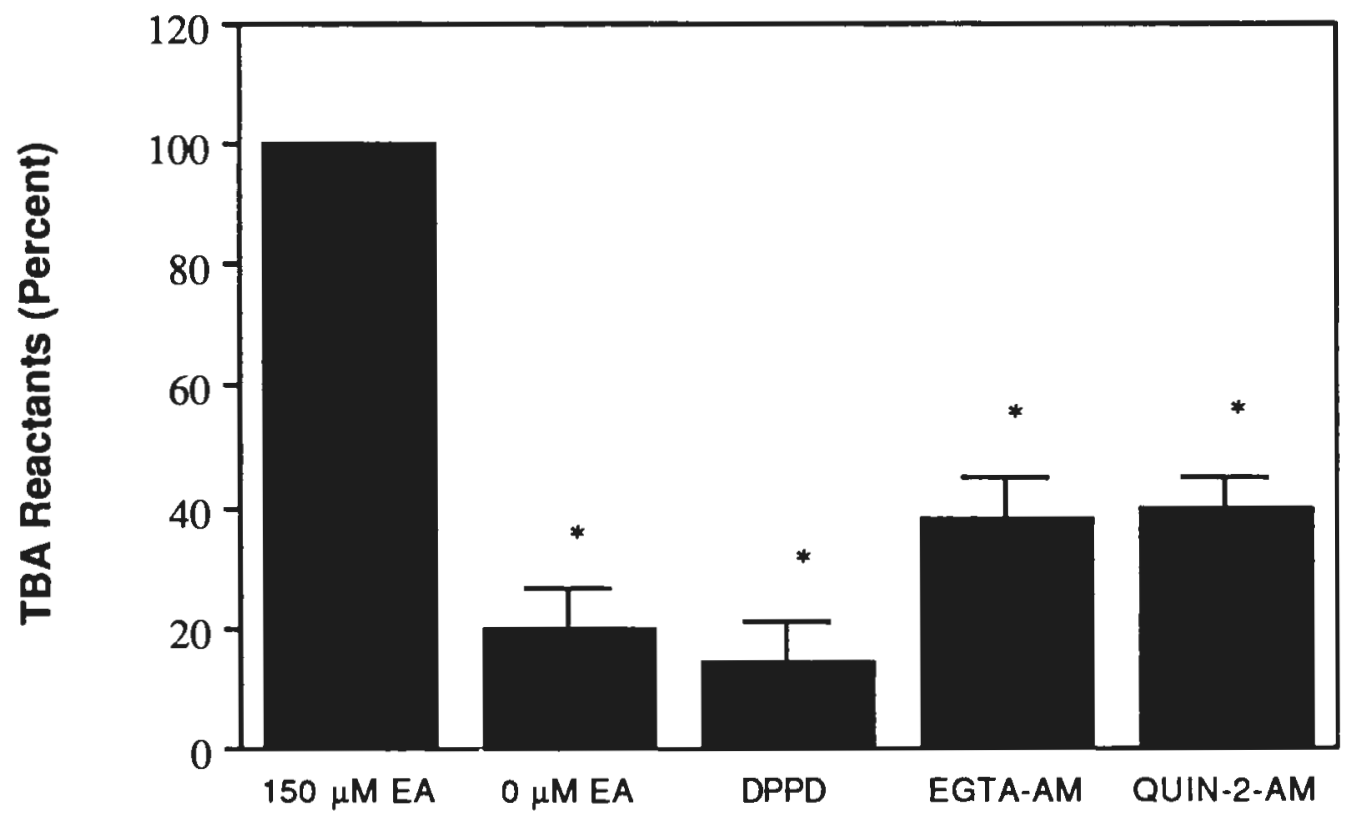


Figure 12. Effect of $150 \mu \mathrm{MEA}$ on cardiomyocyte mitochondrial membrane potential. Cells were radiolabelled with $0.25 \mu \mathrm{Ci} / \mathrm{ml}$ of $\left[{ }^{3} \mathrm{H}\right]-\mathrm{TPMP}$ for $1 \mathrm{hr}$ at $37{ }^{\circ} \mathrm{C}$. At that time cultures were rinsed twice with Hank's balanced salt solution (1.2 $\left.\mathrm{mM} \mathrm{Ca}^{2+}\right)$ containing $25 \mathrm{mM}$ Hepes, $\mathrm{pH} 7.4$ at $37^{\circ} \mathrm{C}$. Myocytes were then incubated in Hank's balanced salt solution, $0.3 \%$ ethanol, for $30-75 \mathrm{~min}$ at $37^{\circ} \mathrm{C}$, in the absence (ㅁ) or presence ( () of $150 \mu \mathrm{M} \mathrm{EA}$. Myocytes were also incubated with $25 \mu \mathrm{M} \mathrm{CCCP}(\bullet), 0.5 \% \mathrm{DMSO}(\mathrm{v} / \mathrm{v})$, as a positive control. Values represent the mean $\pm \mathrm{SD}$ of $n=7(0 \mu \mathrm{M} \mathrm{EA}, 150 \mu \mathrm{M} \mathrm{EA})$, and $n=6(25$ $\mu \mathrm{M}$ CCCP). Differences between EA treated cells and controls cells are significant at $\mathrm{p}<0.01$ $\left(^{*}\right)$ and between CCCP treated cells and control cells. 


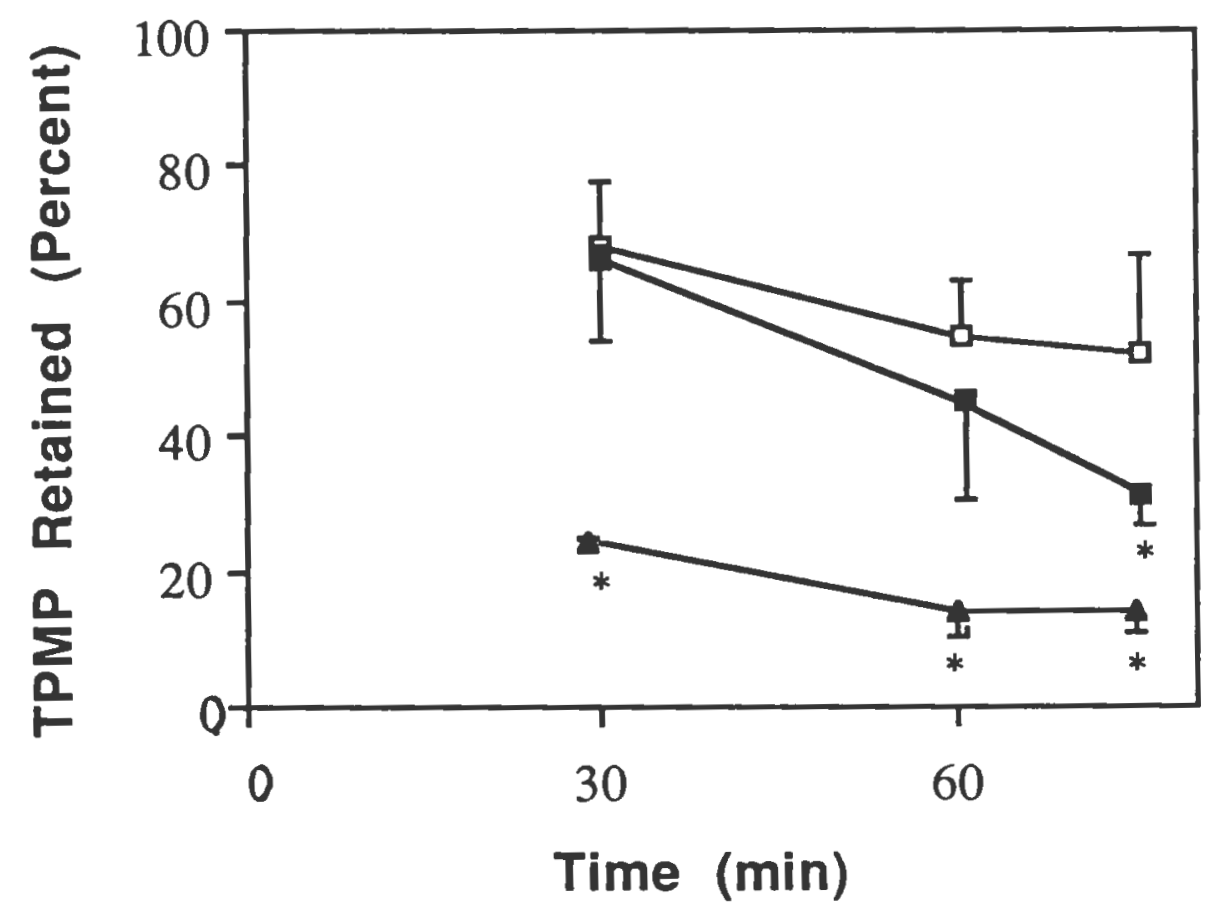


Figure 13. Effect of intracellular $\mathrm{Ca}^{2+}$ chelators, EGTA-AM and Quin-2-AM, and antioxidant DPPD on EA-induced inactivation of glyceraldehyde 3-phosphare dehydrogenase activity. Cardiomyocytes were preincubated with $120 \mu \mathrm{M}$ Quin-2-AM, EGTA-AM or 0.4-0.6\% DMSO for $45 \mathrm{~min}$. At that time cultures were rinsed twice with Hank's balanced salt solution $\left(1.2 \mathrm{mM} \mathrm{Ca}^{2+}\right)$, containing $25 \mathrm{mM}$ Hepes, $\mathrm{pH} 7.4$ at $37^{\circ} \mathrm{C}$. Myocytes were then incubated in Hank's balanced salt solution, $0.3 \%$ ethanol, at $37^{\circ} \mathrm{C}$ for $1 \mathrm{hr}$ in the absence ( $\square$ ) or presence ( $\square$ ) of $150 \mu \mathrm{M}$ EA . Separate cardiomyocyte preparations were also treated with $5 \mu \mathrm{M}$ DPPD concurrently with or without $150 \mu \mathrm{M}$ EA, in Hank's balance salt solution, $0.3 \%$ ethanol $(\mathrm{v} / \mathrm{v})$ and $0.4 \%$ DMSO $(\mathrm{v} / \mathrm{v})$. Values represent the mean $\pm \operatorname{SD}$ of 4 separate myocyte preparations. Differences between EA treated cells and control cells are significant at $\mathrm{p}<0.01(*)$. 


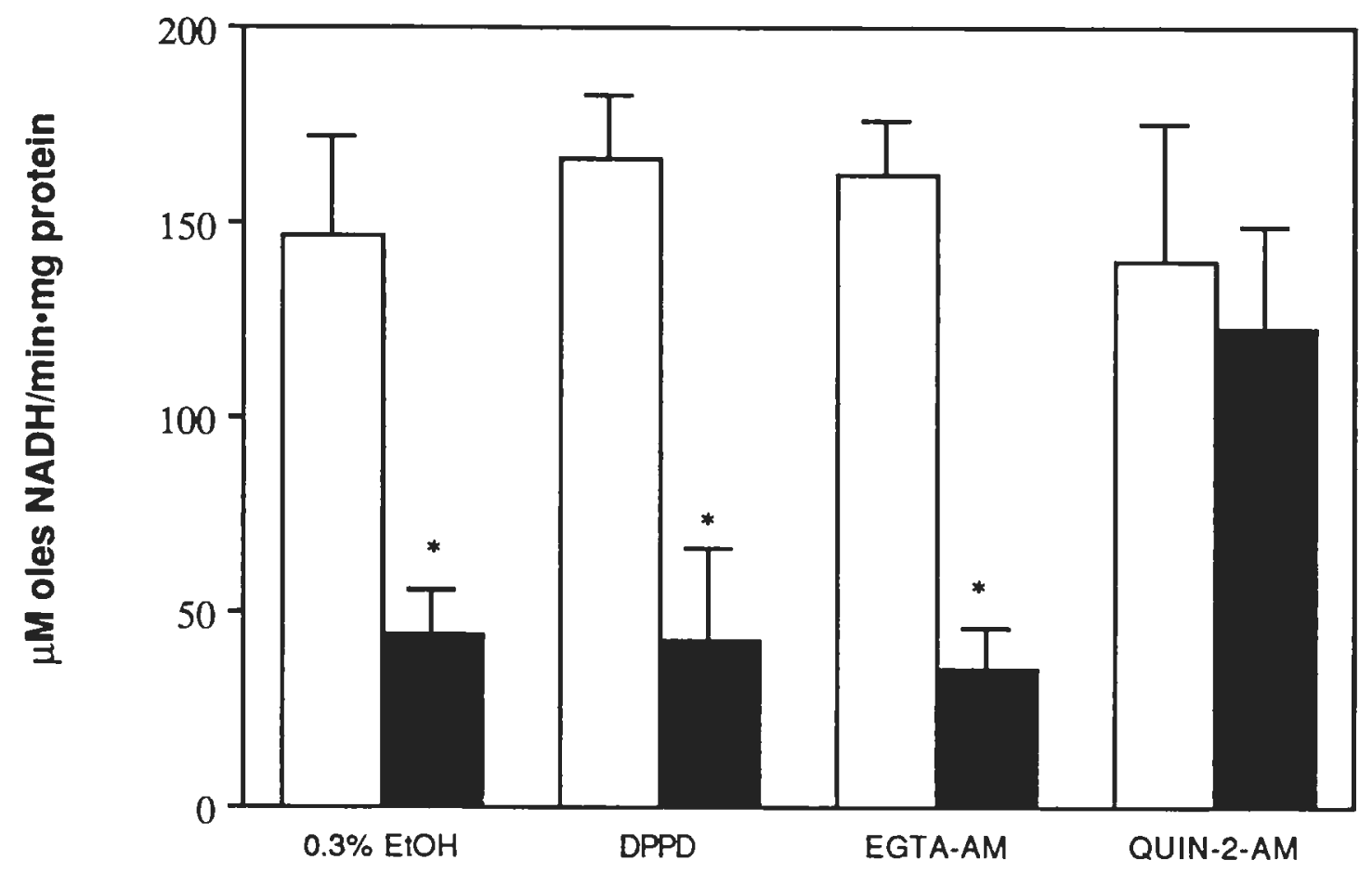


Table 1. Effect of DPPD on EA-induced cardiomyocyte GSH depletion.

\begin{tabular}{lc}
\hline \multicolumn{1}{c}{ Treatment } & nmoles GSH/mg protein \\
\hline \multicolumn{1}{c}{ O $\mu \mathrm{MEA}$} & $19 \pm 3$ \\
(-) DPPD & $17 \pm 4$ \\
(+) DPPD & \\
$150 \mu \mathrm{M} \mathrm{EA}$ & $3 \pm 2^{*}$ \\
(-) DPPD & $3 \pm 1^{*}$ \\
(+) DPPD & \\
\hline
\end{tabular}

Myocytes were incubated in Hank's balanced salt solution containing $1.2 \mathrm{mM} \mathrm{Ca}^{2+}, 0.3 \%$ ethanol, and buffered with $25 \mathrm{mM}$ Hepes to $\mathrm{pH} 7.4$ at $37^{\circ} \mathrm{C}$, in the absence or presence of $150 \mu \mathrm{M} \mathrm{EA}$, with or without $5 \mu \mathrm{M}$ DPPD. At the end of $30 \mathrm{~min}$ incubation, GSH levels were determined by HPLC method of Reed et al (37). Values represent the mean \pm SD of measurements from 3 separate myocyte separations. Differences between EA treated cells and control cells are significant at $p<0.01(*)$. 
Table 2. Time-dependent effect of $150 \mu M$ EA on cardiomyocyte ATP levels.

\begin{tabular}{ccc}
\hline Time(mins) & \multicolumn{2}{c}{ nmoles ATP/mg protein } \\
& Control & $150 \mu \mathrm{M} \mathrm{EA}$ \\
& & \\
7 & $52 \pm 5$ & $53 \pm 11$ \\
15 & $52 \pm 5$ & $53 \pm 8$ \\
30 & $52 \pm 7$ & $55 \pm 6$ \\
60 & $55 \pm 3$ & $52 \pm 2$ \\
75 & $55 \pm 6$ & $46 \pm 7 *$ \\
\hline
\end{tabular}

Myocytes were incubated in Hank's balanced salt solution containing $1.2 \mathrm{mM}$ $\mathrm{Ca}^{2+}, 0.3 \%$ ethanol, and buffered with $25 \mathrm{mM}$ Hepes to $\mathrm{pH} 7.4$ at $37^{\circ} \mathrm{C}$, in the absence or presence of $150 \mu \mathrm{M}$ EA. At times indicated ATP levels were determined by the luciferin-luciferase method as mentioned in the method section. Values represent the mean \pm SD of measurements from 4 separate myocyte preparations. Differences between EA treated cells and control cells are significant at $\mathrm{p}<0.05(*)$. 


\section{DISCUSSION}

Using exposure to EA as a model of chemically-induced cytotoxicity, we examined the relationship between intracellular thiol status, $\mathrm{Ca}^{2+}$ homeostasis, and myocardial cell death. The maintenance of intracellular GSH has been suggested to play a pivotal role in the maintenance of cell viability $(1,2,4)$. Results of previous studies suggest that depletion of GSH levels to less than $10-15 \%$ of initial levels is generally observed to correlate with the loss of cell viability (6). These results have been interpreted to suggest that the extent of cell death following the chemical depletion of GSH corresponds to depletion of the mitochondrial pool, which comprises $15 \%$ of the total intracellular GSH (4). We observed a rapid depletion of intracellular GSH levels to less than $1 \%$ within $1 \mathrm{hr}$ in the presence of $150 \mu \mathrm{M} \mathrm{EA}$. These data demonstrate that the EA challenge in our model system was of sufficient magnitude to deplete almost all of the intracellular GSH, including the mitochondrial pool.

Recent studies have led to the suggestion that the alteration of protein thiols in concert with the depletion of intracellular GSH may be responsible for the loss of protection against a chemically-induced oxidative stress and subsequent loss of cell viability (43). EA has been effectively used to deplete intracellular thiols in isolated rat hepatocytes (3). Modification of these protein thiol groups may limit the enzymatic capacity of many critical enzymes. Such enzymes include sarcoplasmic reticular and sarcolemmal $\mathrm{Ca}^{2+}$-ATPases, and modification of these enzymes result in the perturbation of intracellular $\mathrm{Ca}^{2+}$ homeostasis preceding cell injury $(10,11)$. Results described herein, demonstrate a time-dependent depletion of protein thiols ( $30 \%$ depletion by $1 \mathrm{hr}$ ), which follows the depletion of intracellular GSH. This pool of depleted protein thiols may include thiol containing enzymes responsible for maintaining intracellular $\mathrm{Ca}^{2+}$ homeostasis. Thus this alteration of critical thiol groups may be linked to the perturbation of $\mathrm{Ca}^{2+}$ homeostasis, 
and the resultant elevation of cytosolic free $\mathrm{Ca}^{2+}$ may contribute to cell death.

Given the proposed relationship between thiol status and $\mathrm{Ca}^{2+}$ homeostasis and the possible significance of these events to cell viability, we examined intracellular $\mathrm{Ca}^{2+}$ homeostasis in the face of an EA challenge. A time and concentration-dependent increase in cytosolic free $\mathrm{Ca}^{2+}$ levels was observed in myocardial cells, as measured by the elevation of phosphorylase $a$ activity. The elevation of intracellular $\mathrm{Ca}^{2+}$ followed the depletion of intracellular GSH and protein thiols, and preceded the onset of cell death. The temporal relationship we observed suggests that an EA challenge may alter thiol groups critical to the regulation of intracellular $\mathrm{Ca}^{2+}$, resulting in elevated cytosolic $\mathrm{Ca}^{2+}$. This perturbation of $\mathrm{Ca}^{2+}$ homeostasis may contribute to cell injury due to $\mathrm{Ca}^{2+}$-activated processes.

This temporal relationship suggested that intracellular thiol depletion may be linked to the perturbation of $\mathrm{Ca}^{2+}$ homeostasis that preceded cell death. We next attempted to determine if the observed $\mathrm{Ca}^{2+}$ increase was responsible for the cell injury. Toward this end, we tested the effect of two specific intracellular $\mathrm{Ca}^{2+}$ chelators, Quin-2-AM and EGTA-AM, on EA toxicity. While both the chelators protected the cells, contrary to expectations, they did not do so by lowering $\mathrm{Ca}^{2+}$. These results do not support interpretations from other studies that elevated $\mathrm{Ca}^{2+}$ levels are a primary cause of cell death.

Besides its proposed importance in $\mathrm{Ca}^{2+}$ homeostasis, GSH is a major intracellular antioxidant. The extent of GSH depletion caused by EA treatment suggested a possible role of peroxidative damage in our system of chemically-induced injury. Indeed, our results indicate that EA-induced thiol depletion results in lipid peroxidation. This rapid depletion of intracellular GSH may incapacitate the effective reduction of free radicals and the resultant generation of partially reduced oxygen species may initiate an iron-dependent mechanism of peroxidative damage to the cellular membrane (22). The antioxidant DPPD 
was used to investigate the importance of the loss of GSH antioxidant protection in a situation where GSH is depleted due to its alkylation by EA. We also observed the effect of DPPD on EA-induced lipid peroxidation, in the absence of GSH as an antioxidant. DPPD protected cardiomyocytes in the face of an EA challenge that virtually eliminated intracellular GSH, and also reduced the subsequent lipid peroxidation by $90 \%$. Furthermore, the antioxidant DPPD conferred 89\% protection against EA-induced cell death, but had no effect on the elevated phosphorylase $a$ activity. The protective property of DPPD may be attributed exclusively to its ability to prevent lipid peroxidation (9). These data showed that elevated cytosolic $\mathrm{Ca}^{2+}$ alone had no effect on cell viability over the time course of our experiments. However lipid peroxidation appeared to be a key factor in the onset of cell death.

Treatment of the cells with the $\mathrm{Ca}^{2+}$ chelators Quin-2-AM and EGTA-AM, markedly decreased lipid peroxidation by $60 \%$ and $62 \%$, respectively. The ability of iron to undergo redox reactions linked to single-electron cycling is well known. This Fenton-type of reaction which generates free radicals, may possibly interact with the cellular membrane and cause lipid peroxidation. The protective action of the $\mathrm{Ca}^{2+}$ chelators may be more complex to explain. One possibility is that chelation of endogenous iron may protect against lipid peroxidation, which would inhibit a Fenton-type reaction (42).

While our data supports a primary role for peroxidative damage in EA-induced cell death, it was also possible that EA treatment might compromise cellular energy status. Our results demonstrate that EA inhibits G3PD activity, thus demonstrating a potential to inhibit the enzymatic activity of other thiol containing enzymes. This inhibition of such thiol containing enzymes may, in turn, lead to an alteration in normal cellular ATP production. Results of previous studies conducted on myocardial cells have demonstrated that ATP levels may be depleted to $50 \%$ of their initial levels without any corresponding 
decrease in cell viability (45). We monitored the mitochondrial membrane potential and cellular ATP levels, as an important indicator of cellular energy status. Our data indicate that ATP levels did not decrease appreciably ( $<16 \%$ by $75 \mathrm{~min}$ ) and mitochondrial membrane potential is not significantly impaired during EA exposure. These results suggest that the EA-induced alteration of cellular energy status does not play a major role in the onset of cell injury in this model system.

Taken collectively, the results of this study suggest that while elevated cytosolic free $\mathrm{Ca}^{2+}$ may contribute to the cell injury from thiol depletion, we observed, it alone is not the cause of cell death; oxidative damage is a primary requisite. The fact that EA by itself does not generate any free radicals, leads to further speculation regarding the source of oxidative damage in our model system. This study also demonstrates the utility of EAtreated myocytes as a model to study the biochemical events involved in oxidative stress. 


\section{REFERENCES}

1. Orrenius, S., and Nicotera, P. On the role of calcium in chemical toxicity. Arch. Toxicol. Suppl. 11: 11-19 (1987).

2. Orrenius, S., McConkey, D. J., Bellomo, G., and Nicotera, P. Role of $\mathrm{Ca}^{2+}$ in toxic cell killing. TIPS 10: 281-285 (1989).

3. Pascoe, G. A., Olafsdottir, K., and Reed, D. J. Vitamin E protection against chemical-induced cell injury. Arch. Biochem. Biophys. 256: 150-158 (1987).

4. Meredith, M. J., and Reed, D. J. Depletion in vitro of mitochondrial glutathione in rat hepatocytes and enhancement of lipid peroxidation by adriamycin and 1,3-bis-(2-chloroethyl)-1-nitrosourea (BCNU). Biochem. Pharmacol. 32: 1383-1388 (1983).

5. Koechel, D. A. Ethacrynic acid and related diuretcis:relationship of structure to beneficial and detrimental actions. Ann. Rev. Pharmacol. Toxicol. 21: 265-293 (1981).

6. Reed, D. J. Regulation of reductive processe by glutathione. Biochem. Pharmacol. 35: 7-13 (1986).

7. Olafsdottir, K., Pascoe, G. A. and Reed, D.J. Mitochondrial glutathione status during $\mathrm{Ca}^{2+}$ ionophore-induced injury to isolated hepatocytes. Arch. Biochem. Biophys. 263: 226-235 (1988)

8. Babson, J. R., Abell, N. S., and Reed, D. J. Protective role of glutathione redox cycle against adriamycin-mediated toxicity in isolated hepatocytes. Biochem. Pharmacol. 30: 2299-2304 (1981).

9. Miccadei, S., Kyle, M. E., Gilfore, D., and Farber, J. L. Toxic consequence of the abrupt depletion of glutathione in cultured rat hepatocytes. Arch. Biochem. Biophys. 265: $311-320$ (1988). 
10. Nicotera, P., Moore, M., Mirabelli, F., Bellomo, G., and Orrenius, S. Inhibition of hepatocyte plasma membrane $\mathrm{Ca}^{2+}$ ATPase activity by menandione metabolism and its restoration by thiols. FEBS 181: 149-153 (1985).

11. Pascoe, G. A., and Reed, D. J. Cell calcium, vitamin E and thiol redox systems in cytotoxicity. J. Free Rad. Biol. Med. 6: 209-224 (1989).

12. Reed, D. J. Review of the current status of calcium and thiols in cellular injury. Chem. Res. Toxicol. 3: 495-502 (1990).

13. Birkett, D. J. Mechanism of inactivation of rabbit muscle glyceraldehyde 3-phosphate dehydrogenase by ethacrynic acid. Molecular Pharmacology 9: 209-218 (1972).

14. Nicotera, P., Hartzell, P., Baldi, C., Svensson, S., Bellomo, G., and Orrenius, S. Cystamine induces toxicity in hepatocytes through elevation of cytosolic calcium and the stimulation of a nonlysosomal proteolytic system. J. Biol. Chem. 261: 14628-14635 (1986).

15. Thor, H., Hartzell, P., Svensson, S., Orrenius, S., Mirabelli, F., Marinoni, V., and Bellomo, G. On the role of thiol groups in the inhibition of microsomal $\mathrm{Ca}^{2+}$ sequestration by toxic agents. Biochem. Pharmacol. 34: 3717-3723 (1985).

16. Kyle, M. E., Nakae, D., Sakaida, I., Serroni, A., and Farber, J. L. Protein thiol depletion and the killing of cultured hepatocytes by hydrogen peroxide. Biochem. Pharmacol. 38: 3797-3805 (1989).

17. Thomas, C. E., and Reed, D. J. Effect of extracellular calcium on isolated hepatocytes. I. Induction of oxidative stress and cell injury. J. Pharmacol. Exp. Ther. 245: 493-500 (1988).

18. Smith, M., thor, H., and Orrenius, S. Toxic injury to isolated hepatocytes is not dependent on extracellular calcium. Science 213: 1257-1259 (1981).

19. Schanne, F. A., Kane, A. B., Young, E.E., and Farber, J. L. Calcium dependence 
of toxic cell death : a final common pathway. Science 206: 700-702 (1979).

20. Boobis, A. R., Fawthrop D. J., and Davies, D. S. Mechanisms of cell death. TIPS 10: $275-280$ (1989).

21. Di Monte, D., Bellomo, G., Thor, H., Nicotera, P., and Orrenius, S. Menandione-induced cytotoxicity is associated with protein thiol oxidation and alteration in intracellular $\mathrm{Ca}^{2+}$ homeostasis. Arch. Biochem. Biophys. 235: 343-350 (1984).

22. Masaski, N., Kyle, M. E., Serroni, A., and Farber, J. L. Mitochondrial danage as a mechanism of cell injury in the killing of cultured hepatocytes by tert-butyl hydroperoxide. Arch. Biochem. Biophys. 270: 672- 680 (1989)

23. Masaki, N., Thomas, A. W., Hoek, J. B., and Farber, J. L. Intacellular acidosis protects cultured hepatocytes from the toxic consequences of a loss of a mitochondrial energization. Arch. Biochem. Biophys. 272: 152-161 (1989).

24. Thomas, C. E., and Reed, D. J. Effect of extracellular calcium omission on isolated hepatocytes. II. Loss of mitochondrial membrane potential and protection by inhibitors of uniport calcium transduction. J. Pharmacol. Exp. Therapeut. 245: 501-507 (1988).

25. Shirhatti, V., George, M., Chenery, R., and Krishna, G. Structural requirements for inducing cardiotoxicity by anthracycline antibiotics : studies with neonatal rat cardiac myocytes in culture. Toxicol. Appl. Pharmacol. 84: 173-191 (1986).

26. Bollon, A. P., Nath, K., and Shay, J. W. Establishment of contracting heart muscle cell cultures. Tiss. Cult. Assoc. Man. 3: 637-640 (1980).

27. Wenzel, D. G., Wheaty, J. W., and Byrd, G. D. Effects of nicotine on cultured rat heart cells. Toxicol. Appl. Pharmacol. 17: 774-785 (1970).

28. Huber, S. A., Job, L. P., and Auld, K. R. Influence of sex hormones on coxsackie B-3 virus in BALB/C mice. Cell Immunology 67: 173-189 (1982). 
29. Wenzel, D. G., and Cosma, G. N. A model for measuring comparitive toxicities of cardiotoxic drugs with cultured rat heart myocytes, endothelial cells and fibroblasts. Toxicology 33: 103-115 (1984).

30. Long, O. H., and Moore, T. Elevated cytosolic calcium in rat hepatocytes exposed to carbon tetrachloride. J. Pharmacol. Expt. Ther. 238: 186-191. (1986).

31. Lindstrom, T. D., Anders, M. W., and Remmer, H. Effects of phenobarbital and diethyl maleate on carbon tetrachloride toxicity in isolated rat hepatocytes. Exp. Molec. Pathol. 28: 48-57 (1978).

32. Starke, P. E., Hoek,J. B., and Farber, J. L. Calcium-dependent and calcium-independent mechanisms of irreversible cell injury in cultured hepatocytes. J. Biol. Chem. 261: 3006-3012 (1986).

33. Gilboe, D. P., Larson, K. L., and Nuttall, F. Q. Radioactive method for the assay of glycogen phosphorylases. Anal. Biochem. 47: 20-27 (1972).

34. Slivka, S. R., and Insel, P. A. $\AA_{1}$-adrenergic receptor-mediated phosphoinositide hydrolysis and prostaglandin $\mathrm{E}_{2}$ formation in Madin-Darby canine kidney cells. J. Biol. Chem. 262: 4200-4207 (1987).

35. Sedlak, J., and Lindsay, R. H. Estimation of total, protein-bound and non-protein sulfhydryl groups in tissue with Ellman's reagent. Anal. Biochem. 25: 192-205 (1968).

36. Di Monte, D., Ross, D., Bellomo, G., Eklow, L., and Orrenius, S. Alteration in intracellular thiol status during the metabolism of menandioneby isolated rat hepatocytes. Arch. Biochem. Biophys. 235 : 334-342 (1984).

37. Reed, D. J., Babson, J. R., Beatty, P. W., Brodie, A.E., Ellis, W. W., and Potter, D.W. High-performanceliquid chromatography analysis of nanomole levels of glutathione, glutathione disulfide, and related thiols and disulfides. Anal. Biochem. 106: 55-62 (1980). 
38. Stacey, N. H., and Klaassen, C. D. Copper toxicity in isolated rat hepatocytes. Toxicol. Appl. Pharmacol. 58: 211-220 (1981).

39. Wulff, K., and Doppen, W. in Methods of Enzymatic Analysis (Eds. Bergmeyer, H. U., Bergmeyer, J., and Grabl, M.) 7: 357-364 (1985).

40. Klaassen, C. D., and Fitzgerald, T. J. Metabolism and biliary excretion of ethacrynic acid. J. Pharmacol. Exp. Ther. 191:548-56 (1974).

41. Komorn, R., Cafruny, E. J. Effects of ethacrynic acid on renal protein-bound sulfhydryl groups. J. Pharmacol. Exp. Ther. 148: 367-372 (1965).

42. Aust, S. D., Morehouse, L. A., and Thomas, C. E. Role of metals in oxygen radical reactions. J. Free Radiol. Biol. Med. 1: 3-25 (1985).

43. Orrenius, S. Biochemical mechanisms of cytotoxicity. TIPS 6: S 15-20 (1985).

44. Bradford, M. A rapid and sensitive method for the quantitation of microgram quantities of protein utilizing the principle of protein dye binding. Anal. Biochem. 72: 248-253 (1976).

45. DeLuca, M. A., Ingwall, J. S., and Bittl, J. A. Biochemical responses of myocardial cells in culture to oxygen and glucose deprivation. Biochem. Biophys. Res. Commun. 59: 749-756 (1974). 


\section{BIBLIOGRAPHY}

Andersson, B. S., and Jones, D. P. Use of digitonin fractionation to determine mitochondrial transmembrane ion distribution in cells during anoxia. Anal. Biochem. 146: 164-172 (1985).

Aust, S. D., Morehouse, L. A., and Thomas, C. E. Role of metals in oxygen radical reactions. J. Free Radiol. Biol. Med. 1: 3-25 (1985).

Babson, J. R., Abell, N. S., and Reed, D. J. Protective role of glutathione redox cycle against adriamycin-mediated toxicity in isolated hepatocytes. Biochem. Pharmacol. 30: 2299-2304 (1981).

Bellomo, G., Jewell, S. A., Thor, H., and Orrenius, S. Regulation of intracellular calcium compartmentation: studies with isolated hepatocytes and t-butyl hydrperoxide. Proc. Natl. Acad. Sci. USA. 79: 6842-6846 (1982).

Birkett, D. J. Mechanism of inactivation of rabbit muscle glyceraldehyde 3-phosphate dehydrogenase by ethacrynic acid. Molecular Pharmacology 9: 209-218 (1972).

Boobis, A. R., Fawthrop. D. J., and Davies, D. S. Mechanisms of cell death. TIPS 10: 275-280 (1989).

Boobis, A. R., Seddon, C. E., Nasseri-Sina, P., and Davies, D. S. Evidence for a direct role of intracellular calcium in paracetamol toxicity. Biochem. Pharmacol. 39: 1277-1281 (1990).

Bollon, A. P., Nath, K., and Shay, J. W. Establishment of contracting heart muscle cell cultures. Tiss. Cult. Assoc. Man. 3: 637-640 (1980).

Bradford, M. A rapid and sensitive method for the quantitation of microgram quantities of protein utilizing the principle of protein dye binding. Anal. Biochem. 72: 248-253 (1976).

Brodie, A. E., and Reed, D. J. Reversible oxidation of glyceraldehyde 3-phosphate dehydrogenase thiols in human lung carcinoma cells by hydrogen peroxide. Biochem. Biophys. Res. Comm. 148: 120-125 (1987).

Curtis, M. T., Gilfor, D., and Farber, J. L. Lipid peroxidation increase the molecular order of microsomal membranes. Arch. Biochem. Biophys. 235: 644-649 (1984).

DeLuca, M. A., Ingwall, J. S., and Bittl, J. A. Biochemical responses of myocardial cells in culture to oxygen and glucose deprivation. Biochem. Biophys. Res. Commun. 59: 749-756 (1974).

Di Monte, D., Bellomo, G., Thor, H., Nicotera, P., and Orrenius, S. Menandione-induced cytotoxicity is associated with protein thiol oxidation and alteration in intracellular $\mathrm{Ca}^{2+}$ homeostasis. Arch. Biochem. Biophys. 235: 343-350 (1984).

Di Monte, D., Ross, D., Bellomo, G., Eklow, L., and Orrenius, S. Alteration in intracellular thiol status during the metabolism of menandioneby isolated rat 
hepatocytes. Arch. Biochem. Biophys. 235 : 334-342 (1984).

Farber, J. L., Leonard, T. B., Kyle, M. E., Nakae, D., Serroni, A., and Rogers, S. A. Peroxidation-dependent and peroxidation-independent nechanisms by which acetaminophen kills cultured rat hepatocytes. Arch. Biochem. Biophys. 267: 640-650 (1988).

Farber, J. L. The role of calcium ions in toxic cell injury. Env. Health Persp. 84: 107-111 (1990).

Farber, J. L. The role of calcium in lethal cell injury. Chem. Res. Toxicol. 3: 503-508 (1990).

Fiske, C. F., and Subbarow, Y. The colorimetric determination of phosphorus. J. Biol. Chem. 66: 375-400 (1925).

Fong, K-L., McCay, P. B., Poyer, J. L., Keele, B. B., and Misra, H. Evidence that peroxidation of lysosomal membrane is initiated by hydroxy free radicals produced during flavin enzyme activity. J. Biol. Chem. 248:7792-7797 (1973).

Gilboe, D. P., Larson, K. L., and Nuttall, F. Q. Radioactive method for the assay of glycogen phosphorylases. Anal. Biochem. 47: 20-27 (1972).

Gordon, E. E., and Hartog, M. Localization and characterization of the inhibitory action of ethacrynic acid on glycolysis. Biochem. Pharmacol. 20: 2339-2348 (1971).

Hogberg, J., and Kristoferson, A. A correlation between glutathione levels and cellular damage in isolated hepatocytes. Eur. J. Biochem. 74: 77-82 (1977).

Huber, S. A., Job, L. P., and Auld, K. R. Influence of sex hormones on coxsackie B-3 virus in BALB/C mice. Cell Immunology 67:173-189 (1982).

Jones, D. P., Thor, H., Smith, M. T., Jewell, S. A., and Orrenius, S. Inhibition of ATP-dependent microsomal $\mathrm{Ca}^{2+}$ sequestration during oxidative stress and its prevention by glutathione. J. Biol. Chem. 258: 6390-6393 (1983).

Klaassen, C. D., and Fitzgerald, T. J. Metabolism and biliary excretion of ethacrynic acid. J. Pharmacol. Exp. Ther. 191: 548-556 (1974).

Komorn, R., Cafruny, E. J. Effects of ethacrynic acid on renal protein-bound sulfhydryl groups. J. Pharmacol. Exp. Ther. 148: 367-372 (1965).

Koechel, D. A. Ethacrynic acid and related diuretcis:relationship of structure to beneficial and detrimental actions. Ann. Rev. Pharmacol. Toxicol. 21: 265-293 (1981).

Kyle, M. E., Nakae, D., Sakaida, I., Serroni, A., and Farber, J. L. Protein thiol depletion and the killing of cultured hepatocytes by hydrogen peroxide. Biochem. Pharmacol. 38: 3797-3805 (1989).

Kyle, M. E., Serroni, A. and Farber, J. L. The inhibition of lipid peroxidation by disulfiram prevents the killing of cultured hepatocytes by allyl alcohol, tert-butyl hydroperoxide, hydrogen peroxide and diethyl maleate. Chem. Biol. Interactions 
72: 269-275 (1989).

Lebel, D., Poirier, G. G., and Beaudoin, A. R. A convenient method for the ATPase assay. Anal. Biochem. 85: 86-89 (1978).

Lindstrom, T. D., Anders, M. W., and Remmer, H. Effects of phenobarbital and diethyl maleate on carbon tetrachloride toxicity in isolated rat hepatocytes. Exp. Molec. Pathol. 28: 48-57 (1978).

Long, O. H., and Moore, T. Elevated cytosolic calcium in rat hepatocytes exposed to carbon tetrachloride. J. Pharmacol. Exp. Ther. 238:186-191. (1986).

Masaski, N., Kyle, M. E., Serroni, A., and Farber, J. L. Mitochondrial danage as a mechanism of cell injury in the killing of cultured hepatocytes by tert-butyl hydroperoxide. Arch. Biochem. Biophys. 270: 672-680 (1989)

Masaki, N., Thomas, A. W., Hoek, J. B., and Farber, J. L. Intacellular acidosis protects cultured hepatocytes from the toxic consequences of a loss of a mitochondrial energization. Arch. Biochem. Biophys. 272: 152-161 (1989).

McConkey D. J., Hartzell, P., Duddy, S. K., Hankansson, H., and Orrenius, S. 2, 3, 7, 8-tetrachlorodibenzo-p-dioxin kills immature thymocytes by $\mathrm{Ca}^{2+}$-mediated endonuclease activation. Scinece 242: 256-258 (1988).

Meredith, M. J., and Reed, D. J. Status of the mitochondrial pool of glutathione in the isolated hepatocyte. J. Biol. Chem. 257: 3747-3753 (1982).

Meredith, M. J., and Reed, D. J. Depletion in vitro of mitochondrial glutathione in rat hepatocytes and enhancement of lipid peroxidation by adriamycin and 1,3-bis-(2-chloroethyl)-1-nitrosourea (BCNU). Biochem. Pharmacol. 32: 1383-1388 (1983).

Miccadei, S., Kyle, M. E., Gilfore, D., and Farber, J. L. Toxic consequence of the abrupt depletion of glutathione in cultured rat hepatocytes. Arch. Biochem. Biophys. 265: $311-320$ (1988).

Murphy, E., Coll, K., Rich, T. L., and Williamson, J. R. Hormonal effects of calcium homeostasis in isolated hepatocytes. J. Biol. Chem. 255: 6600-6608 (1980).

Nicotera, P., Moore, M., Mirabelli, F., Bellomo, G., and Orrenius, S. Inhibition of hepatocyte plasma membrane $\mathrm{Ca}^{2+}$ ATPase activity by menandione metabolism and its restoration by thiols. FEBS 181: 149-153 (1985).

Nicotera, P., Hartzell, P., Baldi, C., Svensson, S., Bellomo, G., and Orrenius, S. Cystamine induces toxicity in hepatocytes through elevation of cytosolic calcium and the stimulation of a nonlysosomal proteolytic system. J. Biol. Chem. 261: 14628-14635 (1986).

Nicotera, P., thor, $\mathrm{H}$. and Orrenius, S. Cytosolic-free $\mathrm{Ca}^{2+}$ and cell killing in hepatoma 1 c1c7 cells exposed to chemical anoxia. FASEB 3: 59-64 (1989).

Nicotera, P., Bellomo, G., and Orrenius, S. The role of $\mathrm{Ca}^{2+}$ in cell killing. Chem. Res. 
Toxicol. 3: 484-494 (1990).

Olafsdottir, K., Pascoe, G. A. and Reed, D.J. Mitochondrial glutathione status during $\mathrm{Ca}^{2+}$ ionophore-induced injury to isolated hepatocytes. Arch. Biochem. Biophys. 263: 226-235 (1988).

Orrenius, S. Biochemical mechanisms of cytotoxicity. TIPS 6: S 15-20 (1985).

Orrenius, S., and Nicotera, P. On the role of calcium in chemical toxicity. Arch. Toxicol. Suppl. 11:11-19 (1987).

Orrenius, S., McConkey, D. J., Bellomo, G., and Nicotera, P. Role of $\mathrm{Ca}^{2+}$ in toxic cell killing. TIPS 10: 281-285 (1989).

Pascoe, G. A., Olafsdottir, K., and Reed, D. J. Vitamin E protection against chemical-induced cell injury. Arch. Biochem. Biophys. 256: 150-158 (1987).

Pascoe, G. A., and Reed, D. J. Cell calcium, vitamin E and thiol redox systems in cytotoxicity. J. Free Rad. Biol. Med. 6: 209-224 (1989).

Pounds, J. G. The role of calcium in current approaches to toxicology. Env. Health Persp. 84: 7-15 (1990).

Raspe, E., Ramboer, I., Galand, N., and Boeynaems, J. M. Enhanced release of prostacyclin from quin-2 loaded endothelial cells. Eur. J. Pharmacol. 163: 345-351 (1989).

Reed, D. J., Babson, J. R., Beatty, P. W., Brodie, A.E., Ellis, W. W., and Potter, D.W. High-performanceliquid chromatography analysis of nanomole levels of glutathione, glutathione disulfide, and related thiols and disulfides. Analytical Biochem.106: 55-62 (1980).

Reed, D. J. Regulation of reductive processe by glutathione. Biochem. Pharmacol. 35: 7-13 (1986).

Reed, D. J. Review of the current status of calcium and thiols in cellular injury. Chem. Res. Toxicol. 3: 495-502 (1990).

Reed, D. J., Pascoe, G. A. and Thomas, C. E. Extracellular calcium effcts on cell viability and thiol homeostasis. Env. Health Persp. 84: 113-120 (1990).

Schanne, F. A., Kane, A. B., Young, E.E., and Farber, J. L. Calcium dependence of toxic cell death : a final common pathway. Science 206: 700-702 (1979).

Scherer, N. M., and Deamer, D. W. Oxidative stress impairs the function of sarcoplasmic reticulum by oxidation of sulfhydryl groups in the $\mathrm{Ca}^{2+}$-ATPase. Arch. Biochem. Biophys. 246: 589-601 (1986).

Sedlak, J., and Lindsay, R. H. Estimation of total, protein-bound and non-protein sulfhydryl groups in tissue with Ellman's reagent. Anal. Biochem. 25: 192-205 (1968). 
Shier, W. T. Serum stimulation of phospholipase $A_{2}$ and prostaglandin release in $3 T 3$ cells is associated with platelet-derived growth-promoting activity. Proc. Natl. Acad. Sci.,USA. 77:131-141 (1980).

Shier, W. T., and DuBourdieu, D. J. Role of phospholipid hydrolysis in the mechanism of toxic cell death by calcium and ionophore A23187. Biochem. Biophys. Res. Comm. 109:106-112 (1982).

Shirhatti, V., George, M., Chenery, R., and Krishna, G. Structural requirements for inducing cardiotoxicity by anthracycline antibiotics : studies with neonatal rat cardiac myocytes in culture. Toxicol. Appl. Pharmacol. 84:173-191 (1986).

Slivka, S. R., and Insel, P. A. å -adrenergic receptor-mediated phosphoinositide hydrolysis and prostaglandin $\mathrm{E}_{2}$ formation in Madin-Darby canine kidney cells. J. Biol. Chem. 262: 4200-4207 (1987).

Smith, M., thor, H., and Orrenius, S. Toxic injury to isolated hepatocytes is not dependent on extracellular calcium. Science 213: 1257-1259 (1981).

Soler, F., Fernandez-Belda, F., and Gomez-Fernandez, J. C. Effect of tetrabhenylboron on the calcium-dependent ATPase activity of sarcoplasmic reticulum. Biochem. Biophys. Res. Comm. 151: 1093-1098 (1988).

Stacey, N. H., and Klaassen, C. D. Copper toxicity in isolated rat hepatocytes. Toxicol. Appl. Pharmacol. 58: 211-220 (1981).

Stalman, W., and Hers, H-G. The stimulation of liver phosphorylase $b$ by AMP, fluoride and sulfate. Eur. J. Biochem. 54: 341-350 (1975).

Starke, P. E., Hoek,J. B., and Farber, J. L. Calcium-dependent and calcium-independent mechanisms of irreversible cell injury in cultured hepatocytes. J. Biol. Chem. 261: 3006-3012 (1986).

Thomas, C. E., and Reed, D. J. Effect of extracellular calcium on isolated hepatocytes. I. Induction of oxidative stress and cell injury. J. Pharmacol. Exp. Ther. 245: 493-500 (1988).

Thomas, C. E., and Reed, D. J. Effect of extracellular calcium omission on isolated hepatocytes. II. Loss of mitochondrial membrane potential and protection by inhibitors of uniport calcium transduction. J. Pharmacol. Exp. Ther. 245:501-507 (1988).

Thomas, C. E., and Reed, D. J. Current status of calcium in hepatocellular injury. Hepatology 10: 375-384 (1989).

Thor, H., Hartzell, P., Svensson, S., Orrenius, S., Mirabelli, F., Marinoni, V., and Bellomo, G. On the role of thiol groups in the inhibition of microsomal $\mathrm{Ca}^{2+}$ sequestration by toxic agents. Biochem. Pharmacol. 34: 3717-3723 (1985).

Tsien, R. Y. New calcium indicators and buffers with high selectivity against magnesium and protons: design, synthesis, and properties of prototype structures. Biochemistry 19: 2396-2404 (1980). 
Tsien, R. Y., Pozzan, T., and Rink, T. J. Calcium homeostasis in intact lymphocytes: cytoplasmic free calcium monitored with a new, intracellularly trapped fluorescent indicator. J. Cell Biol. 94:325-334 (1982).

Uhing, R. J., Janski, A. M., and Graves, D. J. The effect of solvents on nucleotide regulation og glycogen phosphorylase. J. Biol. Chem. 254: 3166-3169 (1979).

Wenzel, D. G., Wheaty, J. W., and Byrd, G. D. Effects of nicotine on cultured rat heart cells. Toxicol. Appl. Pharmacol. 17: 774-785 (1970).

Wenzel, D. G., and Cosma, G. N. A model for measuring comparitive toxicities of cardiotoxic drugs with cultured rat heart myocytes, endothelial cells and fibroblasts. Toxicology 33: 103-115 (1984).

Wulff, K., and Doppen, W. in Methods of Enzymatic Analysis (Eds. Bergmeyer, H. U., Bergmeyer, J., and Grabl, M.) 7: 357-364 (1985).

Younes, M., and Siegers, C. P. Lipid peroxidation as a consequence of glutathione depletion in rat and mouse liver. Res. Comm. Chem. Path. Pharmacol. 27: 119-128 (1980). 